\title{
Inositol transport in preimplantation rabbit embryos: effects of embryo stage, sodium, osmolality and metabolic inhibitors
}

\author{
S. M. Warner, F. V. Conlon and M. T. Kane* \\ Department of Physiology, National University of Ireland, Galway, University Road, Galway, Ireland
}

The preimplantation period in the rabbit consists of a 3 day cleavage stage during which the number of cells increases with little change in embryo size, followed by a 3-4 day blastocyst stage during which the inner cell mass, the blastocoel and the trophectodermal layer are formed and the embryo grows rapidly in size and protein content. This study used $\left[{ }^{3} \mathrm{H}\right]$ inositol to investigate the transport of inositol, an essential component of the phosphatidylinositol signal transduction system, over the 6 days of preimplantation development by rabbit embryos. In the presence of $15 \mu \mathrm{mol}$ inositol $\mathrm{I}^{-1}$ in the incubation medium, there was a small linear increase in inositol uptake from $0.07 \mathrm{pmol}$ per embryo per $h$ at the one-cell stage (day 1) to $0.135 \mathrm{pmol}$ at the late morula (day 3) stage. Inositol uptake increased to $0.58 \mathrm{pmol}$ per embryo per $\mathrm{h}$ for early blastocysts (day 4) and 23.7 pmol for late blastocysts (day 6). There was a significant linear relationship between inositol uptake and blastocyst diameter and surface area. Efflux of inositol from early morulae was minimal (about $1.25 \%$ of embryo content per $h$ ), whereas efflux from mid-blastocysts (day 5) was much greater (about $\mathbf{1 5 . 6 \%}$ of embryo content per $h$ ). Efflux of inositol from both early morulae and mid-blastocysts was increased by decreasing the osmolality of the incubation medium. Varying the osmolality had no effect on inositol uptake up to $2 \mathrm{~h}$. Inositol uptake was dependent on sodium in cleavagestage embryos but independent of sodium in blastocyst stages. In early morulae, inositol uptake was inhibited by glucose and the sodium-dependent hexose transport inhibitor, phloridzin, but not by the facilitated transport inhibitor, phloretin. Inositol uptake in early morulae was saturable; estimates of 0.227 and $0.288 \mathrm{pmol}$ per morula per $h$ for $V_{\max }$ and 0.045 and $0.038 \mu \mathrm{mol} \mathrm{I}{ }^{-1}$ for $K_{\mathrm{m}}$ were obtained for sodium-dependent transport in two separate experiments. All of these results are consistent with the hypothesis that transport in cleavage stages occurs via a sodium myo-inositol transporter (SMIT) protein. Uptake in blastocysts was non-saturable. Uptake into blastocysts appeared to take place by a transcellular rather than a paracellular route.

\section{Introduction}

There is wide research interest in the various roles of inositol, inositol phosphates and phosphoinositides in cell function. Inositol itself acts as a controller of cell volume and osmolality in certain types of cell (for reviews, see Kleinzeller and Ziyadeh, 1990; Burg, 1995).

Glycosylphosphoinositides are used by cells to anchor some proteins to the cell membrane (for review, see Ferguson, 1999) and, related to this, there is evidence that an inositol phosphate glycan may act as an intracellular messenger for insulin (for review, see Jones and Varela-Nieto, 1998). There is also evidence that a polyphosphoinositide, phosphatidylinositol 3,4,5trisphosphate, may function as a second messenger for certain growth factors (for reviews, see Varticovski et al., 1994; Leevers et al., 1999). However, most research interest is centered on the phosphatidylinositol (PtdIns) cycle and its role as a signal transduction

*Correspondence

Email: michael.kane@nuigalway.ie system for various neurotransmitters, hormones and growth factors (for reviews, see Berridge, 1992; Shears, 1998). Stimulation of membrane-bound cell receptors by a hormone or other agonist activates phospholipase $\mathrm{C}$ to break down Ptdlns $(4,5) \mathrm{P}_{2}$ to two second messengers, inositol 1,4,5-trisphosphate $\left(\operatorname{Ins}(1,4,5) \mathrm{P}_{3}\right)$ and diacylglycerol. Ins $(1,4,5) \mathrm{P}_{3}$ increases intracellular $\mathrm{Ca}^{2+}$ concentrations and diacylglycerol activates protein kinase $C$, which alters cell function by phosphorylating a range of cell proteins.

The rabbit embryo is a particularly interesting system in which to study the effects of growth factors and their signal transduction systems in early embryos because, unlike other laboratory species, it exhibits a marked increase in growth and protein content during the preimplantation period (see Fig. 1). The protein content and number of cells increase from about $0.16 \mu \mathrm{g}$ protein at the one-cell stage immediately after fertilization (Morgan and Kane, 1993) to about $7 \mu \mathrm{g}$ protein and about 80000 cells in the day 6 blastocyst just before implantation (Daniel, 1964; Morgan and Kane, 1993). In contrast, the mouse blastocyst at implantation has 
$<100$ cells and $20-40 \mathrm{ng}$ of protein (Schiffner and Spielmann, 1976). Related to this difference in preimplantation growth patterns is the difficulty in culturing blastocyst-stage rabbit embryos in vitro. Unlike mouse embryos, the formation and expansion of rabbit blastocysts requires the presence of amino acids and water-soluble vitamins, and growth in vitro is markedly less than growth in utero (for review, see Kane, 1987). One of the vitamins essential for rabbit blastocyst expansion and growth is myo-inositol (Kane, 1988; Fahy and Kane, 1992) and inositol also stimulates zona pellucida shedding or 'hatching' by hamster blastocysts (Kane and Bavister, 1988). It has been demonstrated that $\left[{ }^{3} \mathrm{H}\right]$ inositol is incorporated into the phosphoinositides and inositol phosphates of the Ptdlns cycle by rabbit and cattle blastocysts (Fahy and Kane, 1993; Hynes et al., 2000), and into PtdIns and PtdIns4P by mouse blastocysts (Kane et al., 1992; Higgins and Kane, 2003).

The present study set out to investigate the transport of myo-inositol by rabbit embryos over the 6 days of preimplantation development. The mouse and cow are the only other species in which inositol uptake has been studied in preimplantation embryos; in mice there is a large increase in inositol uptake at the blastocyst stage that is not related to embryo protein content (Kane et al., 1992), whereas in cattle embryos there is little increase in uptake at blastocyst formation (Hynes et al., 2000).

\section{Materials and Methods}

\section{Collection and incubation of embryos}

All embryos were collected from does primed with FSH, ovulated with hCG and artificially inseminated (Kane, 1987). Embryos were collected via a mid-ventral laparotomy under neuroleptoanalgesia (Green, 1975) using Hypnorm (active ingredient, fluanisone) as the analgesic $\left(0.5 \mathrm{ml} \mathrm{kg}^{-1}\right.$, i.m. $)$ and diazepam as the sedative (5 mg kg ${ }^{-1}$, i.v.). Rabbits were killed under anaesthesia after embryo collection by injecting $20 \mathrm{ml}$ air i.v. Onecell embryos (day 1 embryos, $17-21 \mathrm{~h}$ after injection with hCG) and early morulae (day 2 embryos, 42$46 \mathrm{~h}$ after injection with hCG) were collected by flushing the oviduct with Hepes-buffered collection medium (Kane, 1987). Late morulae (day 3 embryos, 69-71 h after injection with hCG), early blastocysts (day 4 embryos, 92-96 h after injection with hCG), mid-blastocysts (day 5 embryos, 118-122 $\mathrm{h}$ after injection with hCG) and late blastocysts (day 6 embryos, 140-144 h after injection with hCG) were collected by flushing the uterine horns. All work on live animals was carried out under license from the Irish Department of Health.

Embryos were washed three times by transfer through collection medium and then incubated at $38.5^{\circ} \mathrm{C}$ in rabbit embryo culture medium under $5 \%$ $\mathrm{CO}_{2}$ in air. The composition of the rabbit embryo culture medium (sodium plus medium) was $0.5 \%(\mathrm{w} / \mathrm{v})$
BSA and $108 \mathrm{mmol}^{\mathrm{NaCl}} \mathrm{I}^{-1}, 4.78 \mathrm{mmol}^{\mathrm{KCl}} \mathrm{I}^{-1}$, $1.71 \mathrm{mmol} \mathrm{CaCl}_{2} \cdot 2 \mathrm{H}_{2} \mathrm{Ol}^{-1}, 1.19 \mathrm{mmol} \mathrm{KH}_{2} \mathrm{PO}_{4} \mathrm{I}^{-1}$, $1.19 \mathrm{mmol} \mathrm{MgSO}_{4} \cdot 7 \mathrm{H}_{2} \mathrm{Ol}^{-1}, 25 \mathrm{mmol} \mathrm{NaHCO}_{3}$ $\mathrm{I}^{-1}$ and $0.5 \mathrm{mmol}$ sodium pyruvate $\mathrm{I}^{-1}$. The concentrations of amino acids, vitamins and trace elements were the same as in Ham's F10 medium (Ham, 1963; Kane and Foote, 1970) with two exceptions: the serine concentration was $3 \mathrm{mmol} \mathrm{I}^{-1}$ (Kane, 1989) and the myo-inositol concentration varied with the experiment. This medium was used in all experiments unless otherwise stated.

A sodium minus medium was made by replacing $\mathrm{NaCl}$ in the standard medium with choline chloride and replacing $\mathrm{NaHCO}_{3}$ with choline bicarbonate on an equimolar basis to study the effect of sodium. However, this medium contained minor amounts of sodium both from sodium pyruvate $\left(0.5 \mathrm{mmol} \mathrm{I}^{-1}\right)$ and from the sodium salts of some amino acids. Media of various osmolalities were made up by varying the total amount of water in the media; osmolalities were checked with a freezing-point depression osmometer. For the experiment to study the effect of temperature, a Hepes-buffered medium with a similar composition to the sodium plus medium was prepared with the exception that $\mathrm{NaHCO}_{3}$ was replaced by $10 \mathrm{mmol}$ Hepes $\mathrm{I}^{-1}$ and the osmolality was adjusted by changes in $\mathrm{NaCl}$ concentration.

Day 1-4 embryos were usually incubated in $100 \mu \mathrm{l}$ drops of medium under liquid paraffin in Nunc four-well dishes. Day 5-6 embryos were incubated in $1 \mathrm{ml}$ medium in Nunc four-well dishes. The duration of incubation, except where otherwise specified, was $2 \mathrm{~h}$. In certain experiments, late blastocysts were ruptured using a $21 \mathrm{G}$ hypodermic needle and the resultant clump of cells from each blastocyst, which remained together as a discrete unit, was incubated to study inositol uptake.

\section{Measurement of $\left[{ }^{3} \mathrm{H}\right]$ inositol uptake by embryos}

The $\left[{ }^{3} \mathrm{H}\right]$ inositol used was myo- $\left[2-{ }^{3} \mathrm{H}\right]$ inositol (NEN, DuPont de Nemours, Bad Homborg; specific activity varying from 20.0 to $24.4 \mathrm{Ci} \mathrm{mmol} \mathrm{I}{ }^{-1}$ ). On the basis of the data from the first experiment, the concentration of $\left[{ }^{3} \mathrm{H}\right]$ inositol used in later experiments was adjusted to take account of both the number and stage of embryos used; however, where treatment comparisons were made, concentrations of $\left[{ }^{3} \mathrm{H}\right]$ inositol were the same across treatments. As described in the protocol of the various experiments, the embryos were washed through three or four drops (about $4 \mathrm{ml}$ per drop) of Hepes-buffered collection medium after incubation. The embryos were then placed in a scintillation vial in $0.5 \mathrm{ml} 10 \%$ (w/v) trichloroacetic acid, after which $10 \mathrm{ml}$ scintillation cocktail (Ready Value, Beckman Coulter, High Wycombe) was added; a small volume of the final wash medium equivalent to the volume in which washed embryos were transferred to the scintillation vial was treated in a similar way, as a control. The samples 
were counted in a liquid scintillation counter. The d.p.m. values and specific activity of the $\left[{ }^{3} \mathrm{H}\right]$ inositol in the culture medium were used to calculate inositol uptake expressed as pmol per embryo per h. Uptake was also expressed as pmol per $\mathrm{cm}^{2}$ per $\mathrm{h}$ for blastocysts.

\section{Experiment 1: effect of embryo stage on inositol uptake}

Embryos of all six stages from days 1-6 were incubated for $2 \mathrm{~h}$ in either $100 \mu \mathrm{l}$ (days 1-4) or $1 \mathrm{ml}$ (days 5-6) drops of medium containing $10 \mu \mathrm{Ci}\left[{ }^{3} \mathrm{H}\right]$ inositol $\mathrm{ml}^{-1}$. Concentration of unlabelled inositol was $15 \mu \mathrm{mol} \mathrm{I}{ }^{-1}$, the concentration shown to be optimal for rabbit blastocyst growth in vitro (Kane, 1989; Fahy and Kane, 1992).

\section{Experiment 2: effect of duration of incubation and temperature on inositol uptake}

The effects of duration of incubation on inositol uptake were examined by incubating day 2 early morulae and day 5 mid-blastocysts in drops of medium (morulae, $100 \mu \mathrm{l}$; blastocysts, $1 \mathrm{ml}$ ) containing $25 \mu \mathrm{Ci}\left[{ }^{3} \mathrm{H}\right]$ inositol $\mathrm{ml}^{-1}$ for 10, 20, 40, 60, 120 or $240 \mathrm{~min}$. Concentration of unlabelled inositol was $15 \mu \mathrm{mol} \mathrm{I} \mathrm{I}^{-1}$.

The effects of temperature in day 2 early morulae, and day 6 intact blastocysts and clumped blastocyst cells incubated in Hepes-buffered medium for $2 \mathrm{~h}$ at $8^{\circ} \mathrm{C}$ and $38^{\circ} \mathrm{C}$ were examined. Morulae and blastocyst cells were incubated in $100 \mu \mathrm{l}$ drops with either 100 (morulae) or 50 (blastocyst cells) $\mu \mathrm{Ci}\left[{ }^{3} \mathrm{H}\right]$ inositol $\mathrm{ml}^{-1}$. Intact blastocysts were incubated in $1 \mathrm{ml}$ drops with $5 \mu \mathrm{Ci}$ $\left[{ }^{3} \mathrm{H}\right]$ inositol $\mathrm{ml}^{-1}$. Concentration of unlabelled inositol was $3 \mu \mathrm{mol} \mathrm{I} \mathrm{I}^{-1}$.

\section{Experiment 3: effect of embryo stage on efflux of $\left[{ }^{3} \mathrm{H}\right]$ inositol}

Efflux of $\left[{ }^{3} \mathrm{H}\right]$ inositol from day 2 early morulae and day 5 mid-blastocysts was examined. Embryos were preloaded with $\left[{ }^{3} \mathrm{H}\right]$ inositol by incubation for $6 \mathrm{~h}$ in drops (morulae, $100 \mu \mathrm{l}$; blastocysts, $1 \mathrm{ml}$ ) of medium without unlabelled inositol but in the presence of either 100 (morulae) or 10 (blastocysts) $\mu \mathrm{Ci}\left[{ }^{3} \mathrm{H}\right]$ inositol $\mathrm{ml}^{-1}$. At the end of the loading period, embryos were removed from the drops, washed three times by transfer to collection medium and then re-incubated in drops of unlabelled medium (morulae, $0.5 \mathrm{ml}$; blastocysts, $1 \mathrm{ml}$ ) for $2 \mathrm{~h}$ and the leakage of inositol from the embryos was quantified.

\section{Experiment 4: sodium dependency of inositol uptake}

Embryos of all six stages from days 1-6 were incubated for $2 \mathrm{~h}$ in either $100 \mu \mathrm{l}$ (days $1-4$ ) or $1 \mathrm{ml}$ (days 5-6) drops of medium, both in sodium plus and sodium minus medium, in the presence of $10 \mu \mathrm{Ci}\left[{ }^{3} \mathrm{H}\right]$ inositol $\mathrm{ml}^{-1}$. The concentration of unlabelled inositol was $15 \mu \mathrm{mol} \mathrm{I}^{-1}$.
Experiment 5: effects of glucose and metabolic inhibitors on inositol transport by morulae

Day 2 early morulae were incubated for $2 \mathrm{~h}$ in $100 \mu \mathrm{l}$ drops in media containing glucose $\left(5 \mathrm{mmol} \mathrm{I}^{-1}\right)$, phloridzin $\left(0.05 \mathrm{mmol} \mathrm{I}^{-1}\right)$ or phloretin $\left(0.1 \mathrm{mmol} \mathrm{I}^{-1}\right)$ in the presence of $50 \mu \mathrm{Ci}\left[{ }^{3} \mathrm{H}\right]$ inositol $\mathrm{ml}^{-1}$. Concentration of unlabelled inositol was $3 \mu \mathrm{mol} \mathrm{I}^{-1}$. The concentration of phloridzin chosen was that known to cause inhibition of sodium-dependent glucose transport (Schultz and Zalusky, 1964); the concentration of phloretin used was that shown by Robinson et al. (1990) to cause $95 \%$ inhibition of sodium-independent glucose transport by rabbit blastocysts. A control treatment with ethanol was used for these treatments because phloridzin and phloretin were dissolved in ethanol.

Experiment 6: effects of osmolality on uptake and efflux of inositol by embryos

For uptake studies, embryos were incubated in media of various osmolalities (mOsmol (kg water) ${ }^{-1}$; low, 180188; normal, 255-262; high, 340-355). Day 2 early morulae were incubated for $40 \mathrm{~min}$ in $100 \mu$ ldrops with $50 \mu \mathrm{Ci}\left[^{3} \mathrm{H}\right]$ inositol $\mathrm{ml}^{-1}$ and $3 \mu \mathrm{mol} \mathrm{I}{ }^{-1}$ unlabelled inositol. Day 5 mid-blastocysts were incubated for $40 \mathrm{~min}$ and $120 \mathrm{~min}$ in $1 \mathrm{ml}$ drops with $10 \mu \mathrm{Ci}\left[{ }^{3} \mathrm{H}\right]$ inositol $\mathrm{ml}^{-1}$. The concentration of unlabelled inositol was $3 \mu \mathrm{mol} \mathrm{I^{-1 }}$.

After loading with $\left[{ }^{3} \mathrm{H}\right]$ inositol, embryos were incubated in media of various osmolalities as described above and efflux was measured. Day 2 early morulae were loaded with $\left[{ }^{3} \mathrm{H}\right]$ inositol by placing them for $6 \mathrm{~h}$ in $100 \mu \mathrm{l}$ drops in normal medium without unlabelled inositol but with $50 \mu \mathrm{Ci}\left[{ }^{3} \mathrm{H}\right]$ inositol $\mathrm{ml}^{-1}$. At the end of the loading period the embryos were washed three times with unlabelled collection medium and then placed in $0.5 \mathrm{ml}$ drops (5-10 morulae per drop) of unlabelled medium of the different osmolalities for measurement of efflux. A $25 \mu \mathrm{l}$ sample of medium was taken at time 0 and the embryos were then incubated for $40 \mathrm{~min}$. At the end of incubation, the embryos and incubation medium were removed separately for counting. Day 5 mid-blastocysts were loaded with $\left[{ }^{3} \mathrm{H}\right]$ inositol by placing them for $6 \mathrm{~h}$ in $1 \mathrm{ml}$ drops in normal medium without unlabelled inositol but with $10 \mu \mathrm{Ci}\left[{ }^{3} \mathrm{H}\right]$ inositol $\mathrm{ml}^{-1}$. At the end of the loading period, the embryos were washed three times with unlabelled collection medium and then placed in $1 \mathrm{ml}$ drops (one blastocyst per drop) in media of the different osmolalities for measurement of efflux. Samples $(25 \mu \mathrm{l})$ of the incubation medium were taken for counting at $0,20,40,60,80,100$ or $120 \mathrm{~min}$ after the start of incubation. At the end of $120 \mathrm{~min}$ incubation, embryos were removed, washed and counted.

\section{Experiment 7: kinetics of inositol uptake}

The kinetics of inositol uptake by early morulae were examined in two experiments by incubating 
(a)
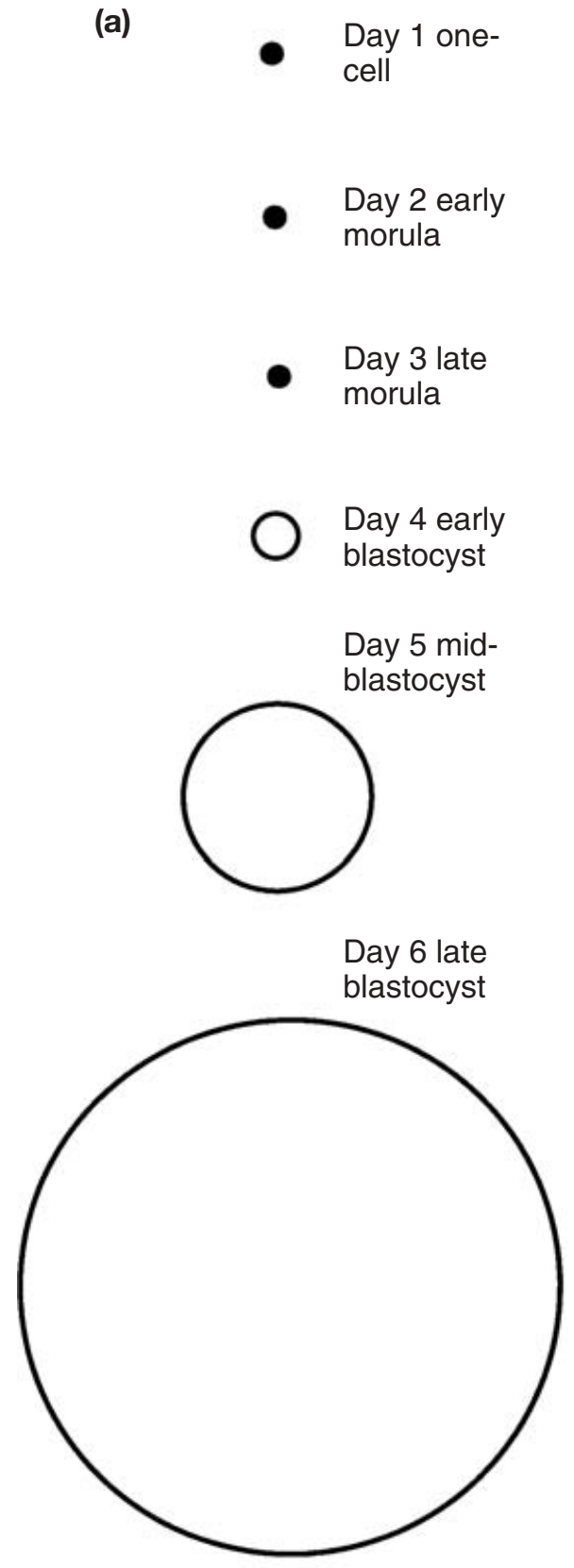

(b)

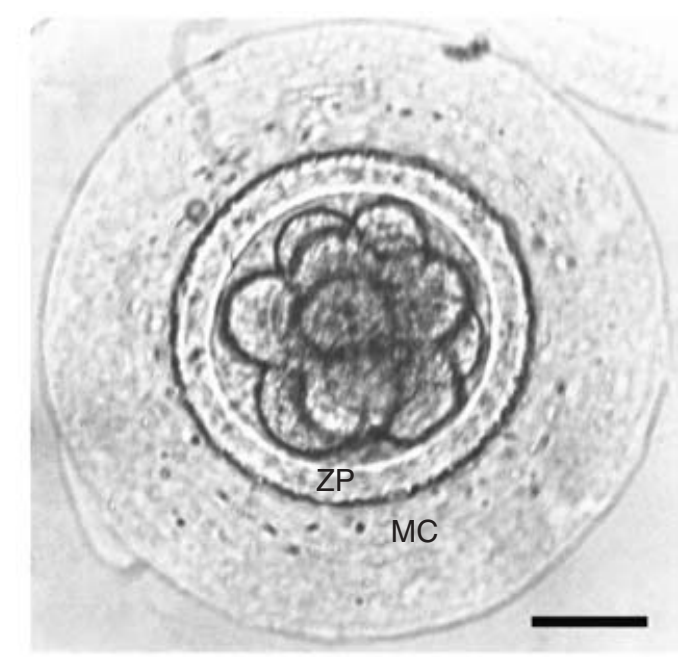

(c)

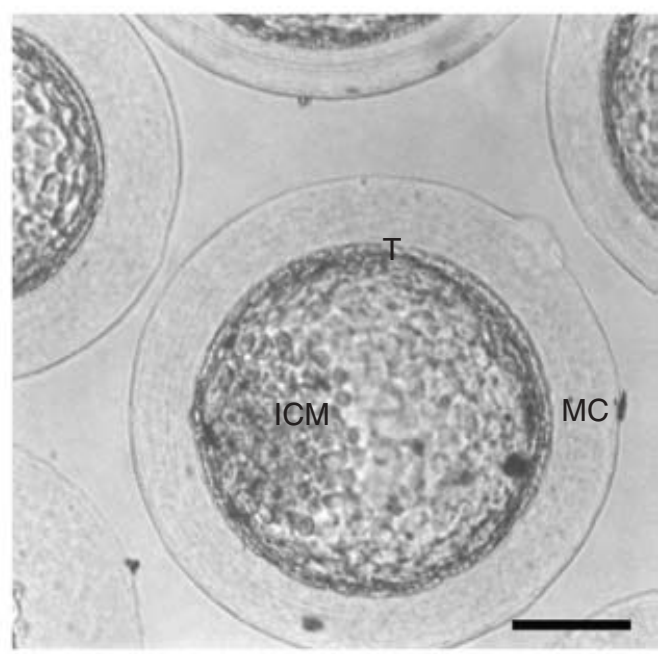

Fig. 1. Rabbit embryos during the 6 days of preimplantation development. (a) The relative sizes of rabbit embryos; sizes refer to embryos without the embryonic coverings (zona pellucida and mucin coat). Filled circles indicate the cleavage or pre-blastocyst stages; open circles indicate the blastocyst stages, all of which possess a blastocoel surrounded by a unicellular layer, trophoblast or trophectoderm. The relatively small inner cell mass from which all the tissues are derived is contained within the blastocyst. Data on the relative sizes of embryos are taken from Alliston and Pardee (1973). (b) A day 2 early morula (ZP, zona pellucida; MC, mucin coat) and (c) a day 4 early blastocyst (T, trophoblast or trophectoderm; ICM, inner cell mass). Scale bars represent (a) $1 \mathrm{~mm}$, (b) $50 \mu \mathrm{m}$ and (c) $100 \mu \mathrm{m}$.

embryos for $2 \mathrm{~h}$ in small groups in $50 \mu \mathrm{l}$ drops (513 embryos per drop), in sodium plus and sodium minus media, in the presence of $100 \mu \mathrm{Ci}\left[{ }^{3} \mathrm{H}\right]$ inositol $\mathrm{ml}^{-1}$ and concentrations of unlabelled inositol varying from
$10 \mu \mathrm{mol} \mathrm{I}^{-1}$ to $5 \mathrm{mmol} \mathrm{I}^{-1}$, and measuring radioactivity in the embryos at the end of incubation. Sodiumdependent transport for each concentration of inositol was calculated by subtracting transport in the absence 
of sodium from transport in the presence of sodium and from these data $K_{\mathrm{m}}$ and $V_{\max }$ values for sodiumdependent transport were determined using EadieHofstee plots.

Day 5 mid-blastocysts were incubated for $2 \mathrm{~h}$ in sodium plus medium in $250 \mu \mathrm{l}$ drops in the presence of $\left.25 \mu \mathrm{Ci}{ }^{3} \mathrm{H}\right]$ inositol $\mathrm{ml}^{-1}$ and various concentrations of unlabelled inositol $\left(10 \mu \mathrm{mol} \mathrm{I}-1-5 \mathrm{mmol} \mathrm{I}^{-1}\right)$.

\section{Experiment 8: effect of inositol concentration in the incubation medium on distribution of inositol uptake between blastocyst cells and blastocyst fluid}

Day 6 late blastocysts were incubated for $2 \mathrm{~h}$ in $1 \mathrm{ml}$ drops in the presence of $10 \mu \mathrm{Ci}\left[{ }^{3} \mathrm{H}\right]$ inositol $\mathrm{ml}^{-1}$ and various concentrations of unlabelled inositol $(10 \mu \mathrm{mol}$ $\left.\mathrm{I}^{-1}-50 \mathrm{mmol} \mathrm{I}^{-1}\right)$. At the end of incubation the embryos were removed, washed three times and placed in a culture dish. Surplus medium was aspirated with a fine needle; the blastocysts were burst and the blastocyst fluid and clump of blastocyst cells were collected separately and inositol uptake into each was quantified.

\section{Experiment 9: effect of duration of incubation and concentration of unlabelled inositol on the uptake of $\left[{ }^{3} \mathrm{H}\right]$ inositol by isolated blastocyst cells}

Day 6 late blastocysts were burst and the clumped cells from each blastocyst incubated in $1 \mathrm{ml}$ drops of medium in the presence of $5 \mu \mathrm{Ci}\left[{ }^{3} \mathrm{H}\right]$ inositol $\mathrm{ml}^{-1}$ and either $10 \mu \mathrm{mol} \mathrm{I}^{-1}$ or $5 \mathrm{mmol} \mathrm{I}^{-1}$ unlabelled inositol. At the end of 4, 20 or 120 min incubation, blastocysts were removed and inositol uptake was quantified.

\section{Experiment 10: evidence for a cellular versus paracellular entry of inositol into the blastocyst cavity}

In an effort to determine whether inositol enters the blastocyst first via the cells and then leaks into the blastocyst cavity (transcellular route) or enters via the trophectodermal junctions and is then taken up from the blastocyst fluid by the cells, the partitioning of $\left[{ }^{3} \mathrm{H}\right]$ inositol between blastocyst cells and fluid in late blastocysts after short-term incubation (2 min) was measured. Day 6 late blastocysts of known diameter and volume were incubated in $1 \mathrm{ml}$ drops of medium (one blastocyst per drop) in the presence of $10 \mu \mathrm{Ci}\left[{ }^{3} \mathrm{H}\right]$ inositol $\mathrm{ml}^{-1}$ and $3 \mu \mathrm{mol} \mathrm{I}{ }^{-1}$ unlabelled inositol. After $2 \mathrm{~min}$ incubation, the blastocysts were removed from the drops, washed once in unlabelled medium and transferred in as small a volume of medium as possible to a culture dish. The excess medium was aspirated from around the blastocysts with a fine needle and the blastocysts were then burst. The clumped cells were taken up into a $10 \mu \mathrm{l}$ glass capillary pipette as a plug of cells and the length of the plug within the capillary tube was measured in $\mathrm{mm}$. The cells and blastocyst fluid were then transferred

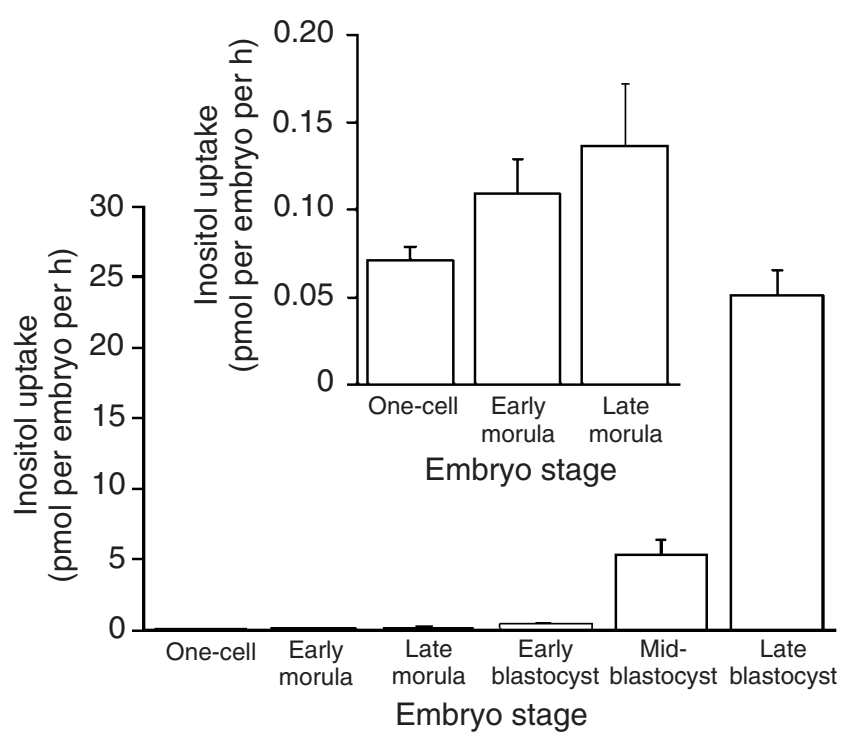

Fig. 2. Uptake of myo-inositol by rabbit embryos from all 6 days of preimplantation development. Concentration of unlabelled inositol was $15 \mu \mathrm{mol} \mathrm{I} \mathrm{I}^{-1}$. Values are means \pm SEM. Inset shows uptake by cleavage stages (days 1-3) on an expanded scale. Details of embryos are as follows: one-cell embryos (day 1 embryos, 17-21 h after injection with hCG), seven replicates of 8-39 embryos per replicate for a total of 119 embryos from six rabbits; early morulae (day 2 embryos, 42-46 h after injection with hCG), seven replicates of 5-15 embryos per replicate for a total of 64 embryos from five rabbits; late morulae (day 3 embryos, $69-71 \mathrm{~h}$ after injection with hCG), five replicates of 4-22 embryos per replicate for a total of 46 embryos from four rabbits; early blastocysts (day 4 embryos, 92$96 \mathrm{~h}$ after injection with hCG), ten replicates of 2-14 embryos per replicate for a total of 59 embryos from four rabbits; mid-blastocysts (day 5 embryos, 118-122 h after injection with hCG), 26 replicates of one or two embryos per replicate for a total of 40 embryos from four rabbits; late blastocysts (day 6 embryos, 140-144 h after injection with hCG), 24 replicates of one embryo per replicate for a total of 24 embryos from four rabbits.

to a scintillation vial for counting. The volume of the blastocyst cells was estimated by two different methods. In method $A$, the volume of cells was calculated on the basis of the length of the cell plug in the capillary pipette and the volume of blastocyst fluid was estimated by subtracting that volume from the volume of the blastocyst. Because the plug of cells was not packed by centrifugation this method tends to give an upper limit to the volume of the blastocyst cells. In method B, blastocyst cell volumes were calculated using the equation described by Jung and Fischer (1988) for rabbit blastocysts:

$$
V=\frac{4}{3} \pi\left[r^{3}-(r-s)^{3}\right]
$$

where $V=$ volume of cells, $r=$ blastocyst radius and $s=$ shell or trophoblastic wall thickness (taken as $6 \mu \mathrm{m}$ ).

The uptake of $\left[{ }^{3} \mathrm{H}\right]$ inositol by blastocyst cells and fluid was measured and expressed in d.p.m. per $\mu$ l using 

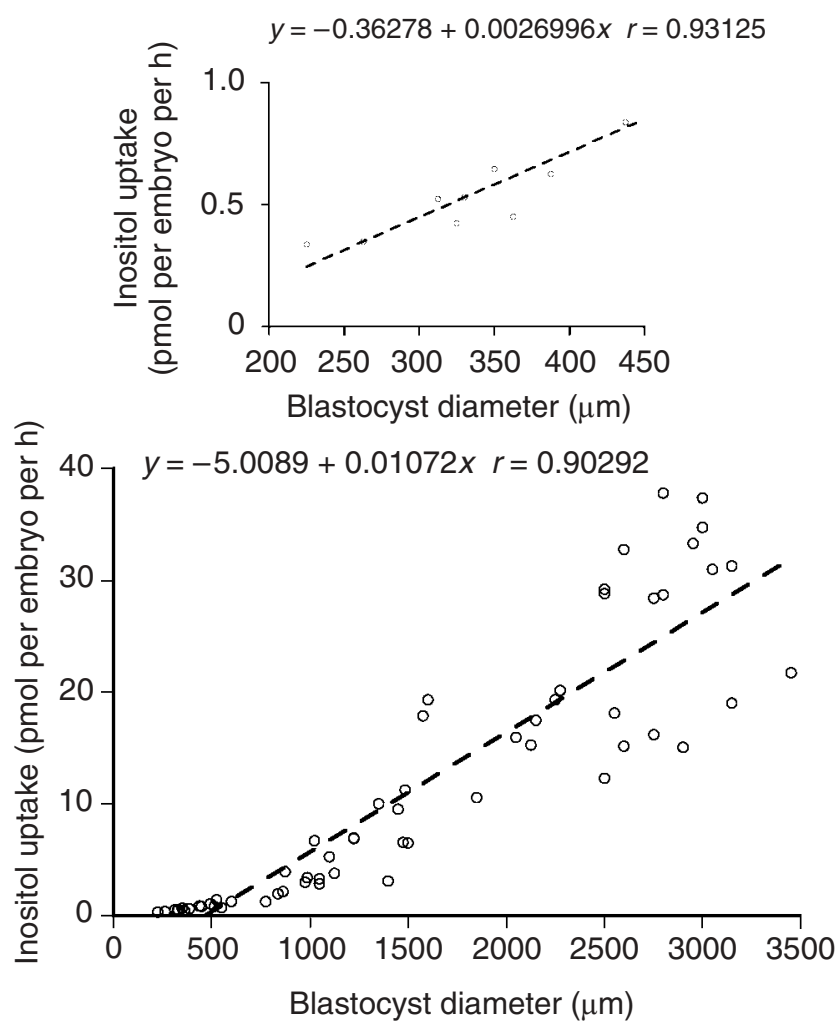

Fig. 3. Relationship between uptake of inositol and blastocyst diameter for day 4,5 and 6 rabbit blastocysts. There was a significant $(P<0.001)$ linear relationship between inositol uptake and blastocyst diameter with a correlation coefficient $r=0.903$. There was also a significant $(P<0.001)$ linear relationship between inositol uptake and blastocyst surface area $(r=0.851$, data not shown). Inset shows the relationship between uptake of inositol and blastocyst diameter for day 4 blastocysts only $(r=0.931)$.

volumes based on both methods for each blastocyst ( $n=51$ blastocysts from eight rabbits). From these data the ratio of uptake into cells to uptake into fluid was calculated for each blastocyst.

\section{Statistical analysis}

Rabbit embryo size varies enormously from the onecell stage to the late blastocyst. Hence, the number of embryos incubated together and counted together in a scintillation vial to provide one experimental unit varied greatly from up to 39 embryos in early experiments on one-cell stages to one embryo at the late blastocyst stage. The results of experiments were analysed by ANOVA after first transforming the data by a logarithmic transformation (Steel and Torie, 1960). Data were analysed further as appropriate either by post hoc comparison of treatment means using Tukey's wprocedure which has an experiment-wise error rate, or by orthogonal comparisons to test for linear and quadratic regression effects (Steel and Torie, 1960). (a)

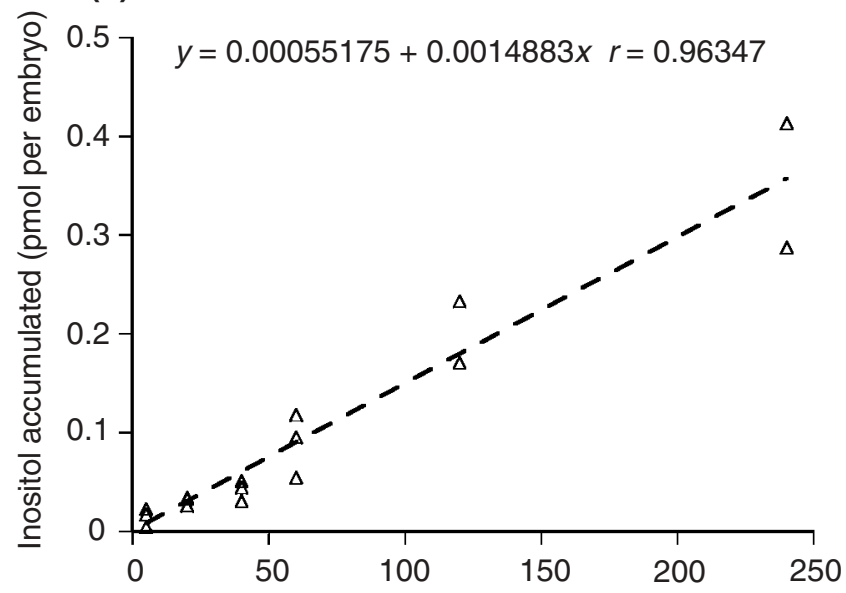

(b)

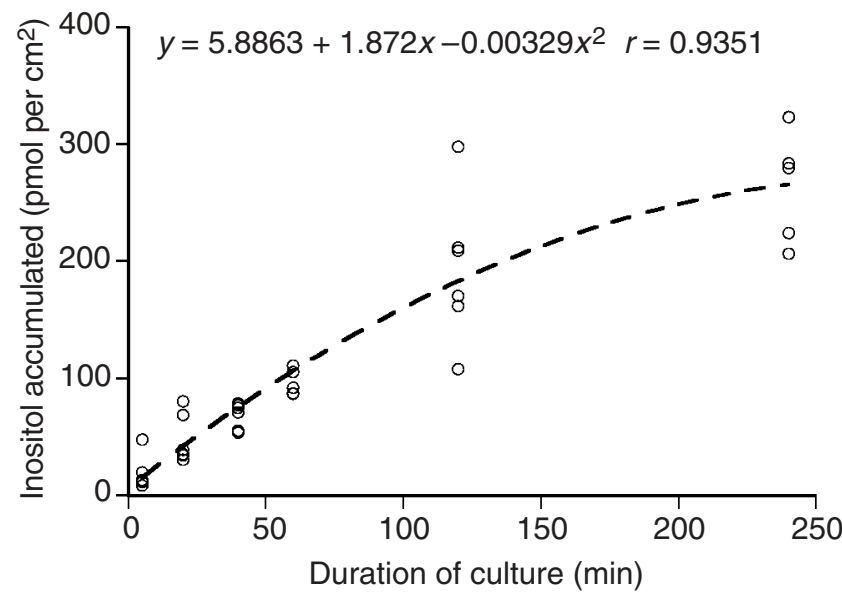

Fig. 4. Effect of duration of incubation on accumulation of inositol by rabbit embryos. (a) Morulae on a per embryo basis and (b) mid-blastocysts on a per $\mathrm{cm}^{2}$ surface area basis. Concentration of unlabelled inositol was $15 \mu \mathrm{mol} \mathrm{I}^{-1}$. Values are means $\pm \mathrm{SEM}$ and individual graph points are based on three or four morulae (a total of 50 morulae from two rabbits) and one blastocyst (a total of 35 blastocysts from three rabbits). There was a significant linear relationship $(P<0.001)$ between duration of incubation and inositol uptake in both morulae and blastocysts; in blastocysts there was also a significant $(P<0.01)$ quadratic component.

\section{Results}

Experiment 1: effect of embryo stage on inositol uptake

The uptake of inositol by rabbit embryos of all six stages from day 1 to day 6 was stage specific (Fig. 2). For the cleavage or pre-blastocyst stages there was a modest but significant $(P<0.05)$ linear increase in inositol uptake from 0.07 pmol per embryo per $\mathrm{h}$ at the onecell stage (day 1 ) to 0.135 pmol per embryo per $\mathrm{h}$ at the late morula (day 3) stage. However, at the blastocyst stages, as the embryos grew and expanded, there was a huge increase in inositol uptake to $0.58 \mathrm{pmol}$ per embryo 
(a)

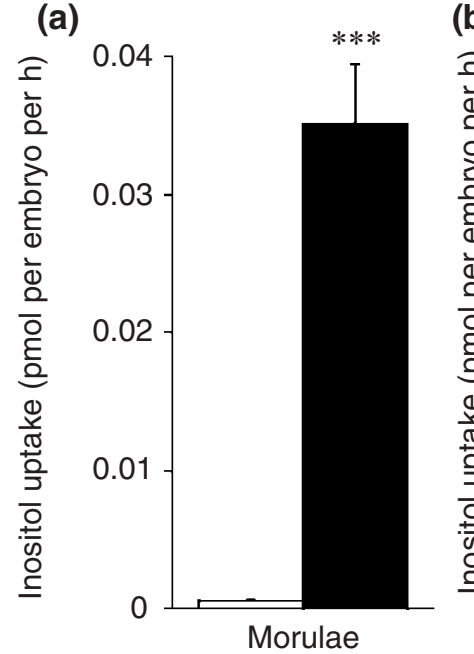

(b)

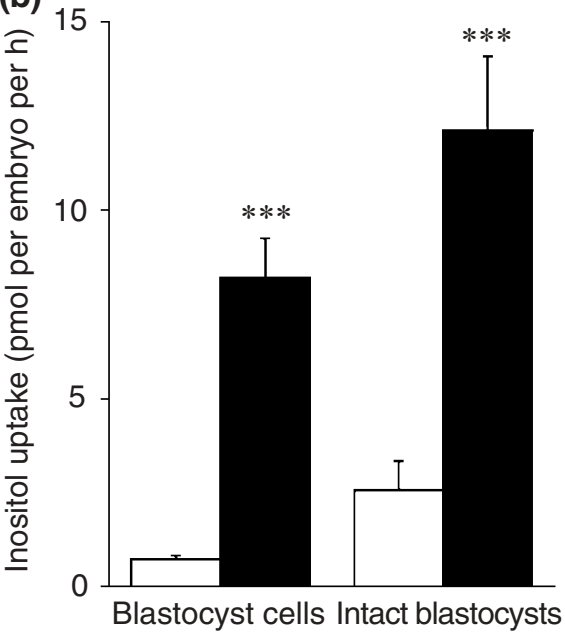

Fig. 5. Effects of temperature, $8^{\circ} \mathrm{C}(\square)$ and $38^{\circ} \mathrm{C}(\mathbf{\square})$, on uptake of inositol by (a) day 2 rabbit morulae and (b) day 6 rabbit blastocysts (intact blastocysts and clumped blastocyst cells). Concentration of unlabelled inositol was $15 \mu \mathrm{mol}$ $\mathrm{I}^{-1}$. Values are means \pm SEM and details of embryos are as follows: morulae, 12 replicates of $4-7$ morulae per treatment (a total of 136 morulae from four rabbits); blastocyst cells, 13-14 replicates of one blastocyst per treatment (27 blastocysts from four rabbits); intact blastocysts, 14-15 replicates of one blastocyst per treatment (29 blastocysts from four rabbits). ${ }^{* * *} P<0.001$.

per $\mathrm{h}$ for early blastocysts (day 4) and 24 pmol per embryo per $\mathrm{h}$ for late blastocysts (day 6). There was a significant $(P<0.001)$ linear relationship between inositol uptake and blastocyst diameter (Fig. 3, $R^{2}=0.83$ ) and between inositol uptake and blastocyst surface area $\left(R^{2}=0.72\right)$. When the data for day 4 early blastocysts only were examined (Fig. 3, inset), a distinctly different regression line with a much lower slope than for all blastocyst stages was obtained (slope coefficient of 0.0027 versus 0.0107 , an almost fourfold difference). This indicates that uptake increases much less rapidly with increasing blastocyst diameter in day 4 blastocysts than in later stages.

Inositol uptake for early blastocysts $(150 \pm 9.0 \mathrm{pmol}$ per $\mathrm{cm}^{2}$ per h) was significantly $(P<0.05)$ greater than that for both mid $\left(115 \pm 10.2 \mathrm{pmol}\right.$ per $\mathrm{cm}^{2}$ per $\left.\mathrm{h}\right)$ and late $\left(107 \pm 6.6 \mathrm{pmol}\right.$ per $\mathrm{cm}^{2}$ per h) blastocysts, when related to blastocyst surface area. However, if the data from the normal control medium in the experiment on the effects of sodium (Expt 4) is included in this analysis, there was no significant effect of blastocyst stage on uptake per $\mathrm{cm}^{2}$.

\section{Experiment 2: effect of duration of incubation and temperature on inositol uptake}

Uptake of inositol by early morulae was linear $(P<$ 0.001 ) for the whole 240 min examined (Fig. 4); in contrast, uptake by mid-blastocysts levelled off after $120 \mathrm{~min}$ as evidenced by a significant quadratic component $(P<0.01)$.
Uptake in both morula and blastocyst stages was markedly dependent on temperature (Fig. 5; $P<0.001$ ). The ratios of inositol uptake at $38^{\circ} \mathrm{C}$ and $8^{\circ} \mathrm{C}$ were 60 , 11 and 4.7 for early morulae, blastocyst cells and intact blastocysts, respectively.

\section{Experiment 3: effect of embryo stage on efflux of $\left.{ }^{3} \mathrm{H}\right]$ inositol}

Efflux of $\left[{ }^{3} \mathrm{H}\right]$ inositol from early morulae was minimal, and was about $1.25 \%$ of the original embryo content per h (inositol leaked after 2 h, $189 \pm 26$ d.p.m; inositol retained $7444 \pm 162$ d.p.m.). In contrast, efflux from mid-blastocysts was much greater, about $15.6 \%$ of embryo content per h (inositol leaked after $2 \mathrm{~h}, 8123+$ 848 d.p.m; inositol retained $26103 \pm 2888$ d.p.m.), indicating that in $6 \mathrm{~h}$ (equivalent to the time taken to load the blastocysts with $\left[{ }^{3} \mathrm{H}\right]$ inositol in this experiment), assuming a constant efflux rate, almost all the inositol would be expected to leak out again.

\section{Experiment 4: sodium dependency of inositol uptake}

The effect of sodium on the uptake of inositol by cleavage-stage rabbit embryos (days 1-3) and blastocyst stages (days 4-6) is shown (Fig. 6). There was a marked difference between cleavage-stage and blastocyst-stage embryos in the effect of sodium on inositol uptake. Removal of sodium from the medium almost completely abolished inositol uptake by cleavage-stage embryos 
(a)

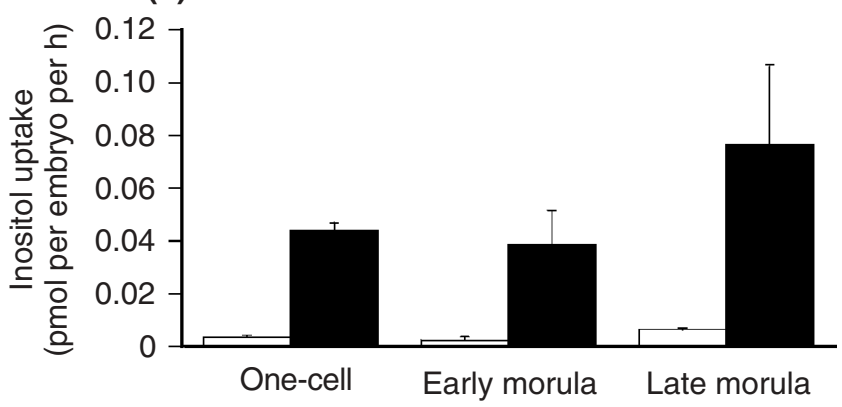

(b)

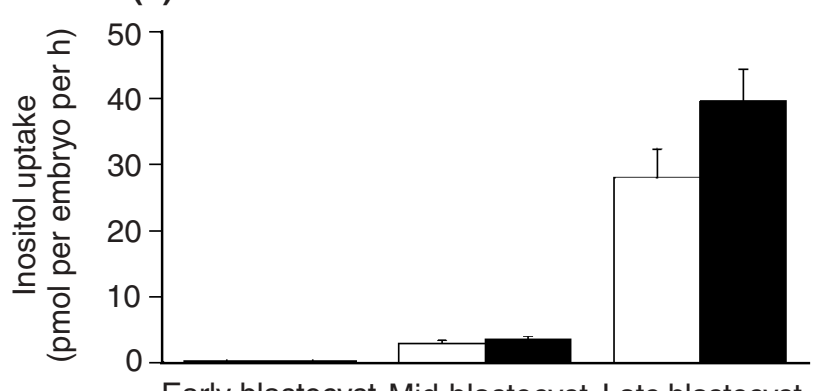

Early blastocyst Mid-blastocyst Late blastocyst

(c)

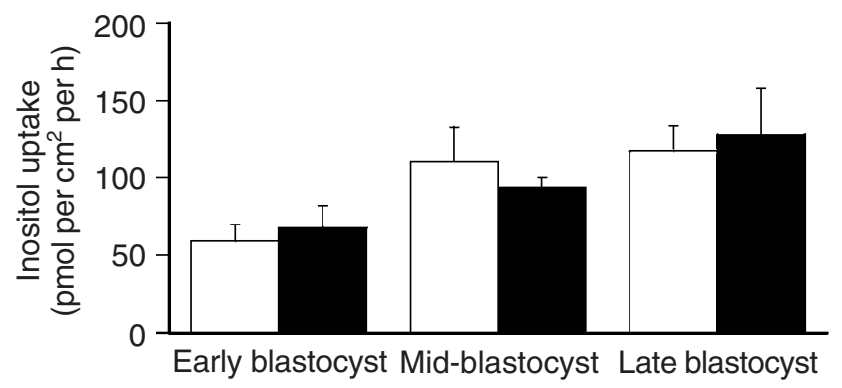

Fig. 6. Effect of sodium on uptake of inositol by rabbit embryos. Bar graphs show uptake in sodium plus (ם) and sodium minus ( $\square$ ) medium. (a) Uptake of inositol per embryo in cleavage-stage embryos; (b) uptake of inositol per embryo in blastocyst stages; and (c) uptake of inositol per $\mathrm{cm}^{2}$ of surface area in blastocyst stages. Concentration of unlabelled inositol was $15 \mu \mathrm{mol} \mathrm{I} \mathrm{I}^{-1}$. Values are means \pm SEM. Details of embryos used are as follows: one-cell embryos, six replicates of 3-5 embryos per replicate for a total of 27-28 embryos per treatment (embryos from two rabbits); early morulae, four replicates of 3-7 embryos per replicate for a total of 20-21 embryos per treatment (embryos from two rabbits); late morulae, three replicates of four embryos per replicate for a total of 12 embryos per treatment (embryos from one rabbit); early blastocysts, 9-10 replicates of 1-3 embryos per replicate for a total of 15-18 embryos per treatment (embryos from three rabbits); midblastocysts, 17-18 replicates of one embryo per replicate for a total of 17-18 embryos per treatment (embryos from two rabbits); late blastocysts, 13-14 replicates of one embryo per replicate for a total of 13-14 embryos per treatment (embryos from three rabbits). There was a significant effect $(P<0.01)$ of sodium on uptake of inositol by all cleavage stages but no significant effect on uptake in blastocyst stages.
(Fig. 6a; $P<0.001$ ) but had no effect on uptake by blastocyst stages (Fig. 6b,c). The presence or absence of sodium in the medium also had no effect on inositol uptake when day 6 late blastocysts were ruptured and the clumped cells from each blastocyst were incubated as an unstructured cellular mass for $2 \mathrm{~h}$ in $1 \mathrm{ml}$ drops of medium (one blastocyst per drop in the presence of $5 \mu \mathrm{Ci}\left[{ }^{3} \mathrm{H}\right]$ inositol $\mathrm{ml}^{-1}$ ). Inositol uptake in sodium plus medium was $12.7 \pm 1.2$ pmol per embryo and in sodium minus medium inositol uptake was $10.0 \pm 1.0 \mathrm{pmol}$ per embryo ( $n=10$ blastocysts per treatment). These results indicate that inositol uptake is sodium dependent during the cleavage stages but sodium independent at the blastocyst stage.

\section{Experiment 5: effects of glucose and metabolic inhibitors on inositol transport by morulae}

Because sodium-dependent inositol transporters in other cells are usually inhibited by glucose and by phloridzin, an inhibitor of sodium-dependent hexose transport, the effects of these compounds and of phloretin (an inhibitor of sodium-independent facilitated hexose transport) on inositol uptake by morulae were examined. Inositol uptake relative to controls in early morulae was significantly reduced by glucose and by phloridzin (Fig. 7). Phloretin had no effect on inositol uptake.

Experiment 6: effects of osmolality on uptake and efflux of inositol by embryos

Uptake of inositol by early morulae and midblastocysts was not significantly affected by the osmolality of the incubation medium (Fig. 8). However, efflux of inositol from early morulae was markedly increased (Fig. 9, $P<0.001$ ) by incubation in the low osmolality medium compared with the normal and the high osmolality media. Efflux of inositol from midblastocysts was also significantly increased by incubation in low osmolality medium at $40 \min (P<0.01)$ and $60 \min (P<0.05)$ after the start of incubation. However, there was no significant effect of osmolality on total efflux at the end of $120 \mathrm{~min}$.

\section{Experiment 7: kinetics of inositol uptake by early morulae and blastocysts}

The effect of inositol concentration in both sodium plus and sodium minus medium on uptake of inositol by early morulae is presented (Fig. 10; data are combined from two replicate experiments). There was a major saturable component of uptake by early morulae as evidenced by the fact that the uptake tended to plateau at higher concentrations. The Eadie-Hofstee plots to determine $V_{\max }$ and $K_{\mathrm{m}}$ values based on the data for sodium-dependent uptake (calculated as the difference between uptake in sodium plus and sodium minus 
(a)

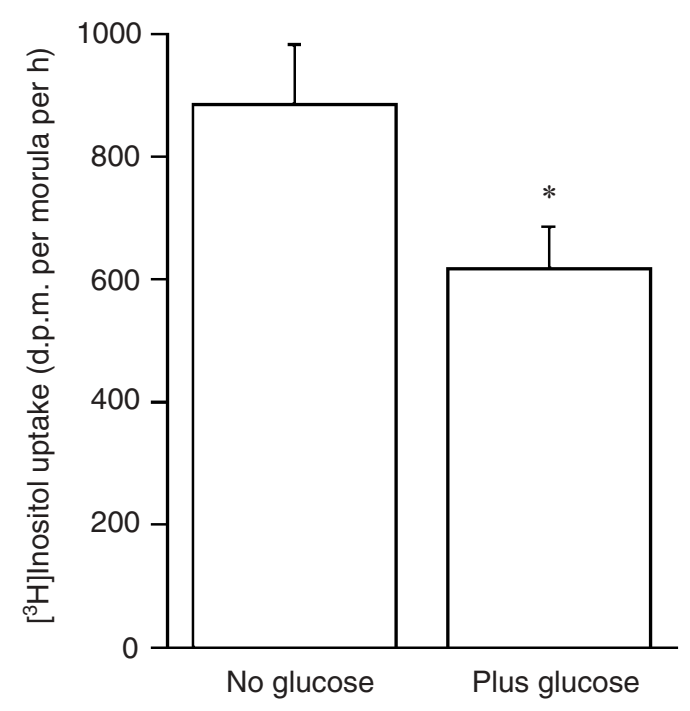

(b)

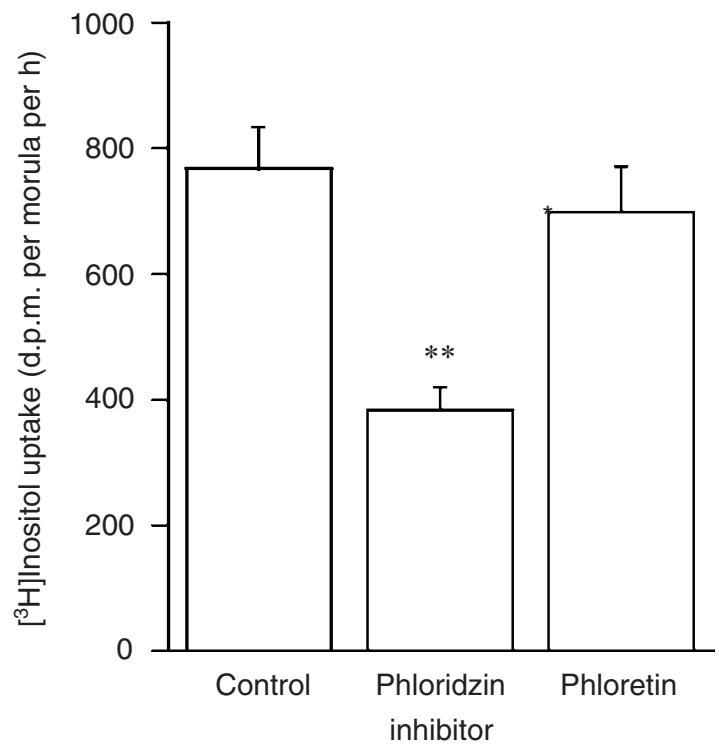

Fig. 7. Effect of (a) glucose $\left(5 \mathrm{mmol} \mathrm{I}^{-1}\right)$ and (b) the metabolic inhibitors phloridzin $\left(0.05 \mathrm{mmol} \mathrm{I}^{-1}\right)$ and phloretin $\left(0.1 \mathrm{mmol} \mathrm{I}^{-1}\right)$ on uptake of $\left.{ }^{3} \mathrm{H}\right]$ inositol by rabbit early morulae. Results are presented as d.p.m. per embryo per $\mathrm{h}$ because in four or five of the replicates for each treatment the unlabelled inositol $\left(3 \mu \mathrm{mol} \mathrm{I} \mathrm{I}^{-1}\right)$ was omitted from the medium. Values are means \pm SEM based on 12-13 replicates of 1-4 morulae per replicate per drop (total of 182 embryos from 18 rabbits). ${ }^{*} P<0.05,{ }^{* *} P<0.01$.

(a)

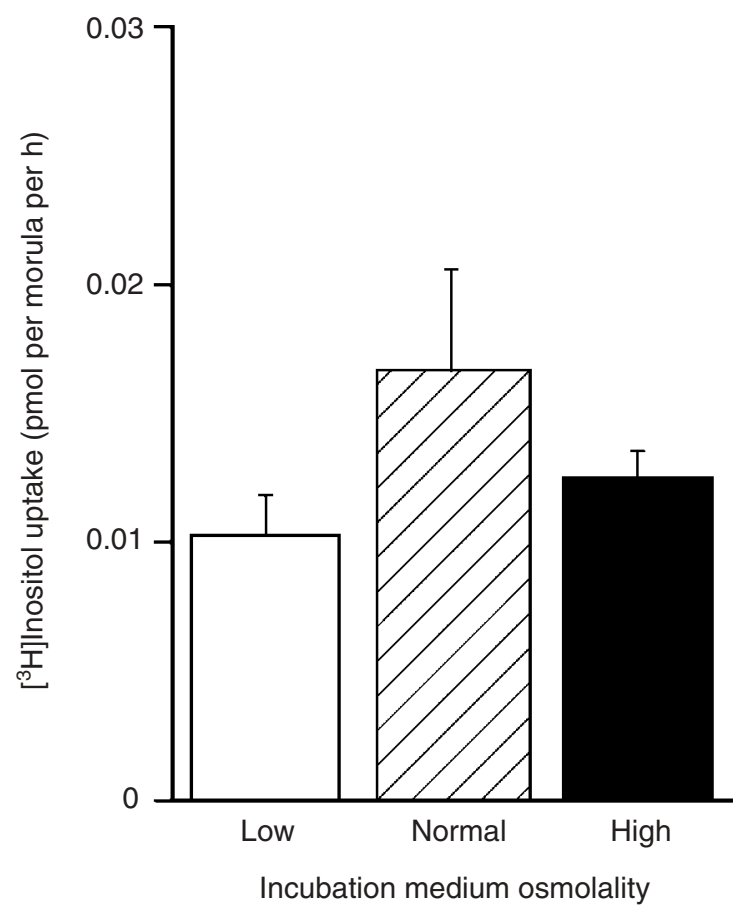

(b)

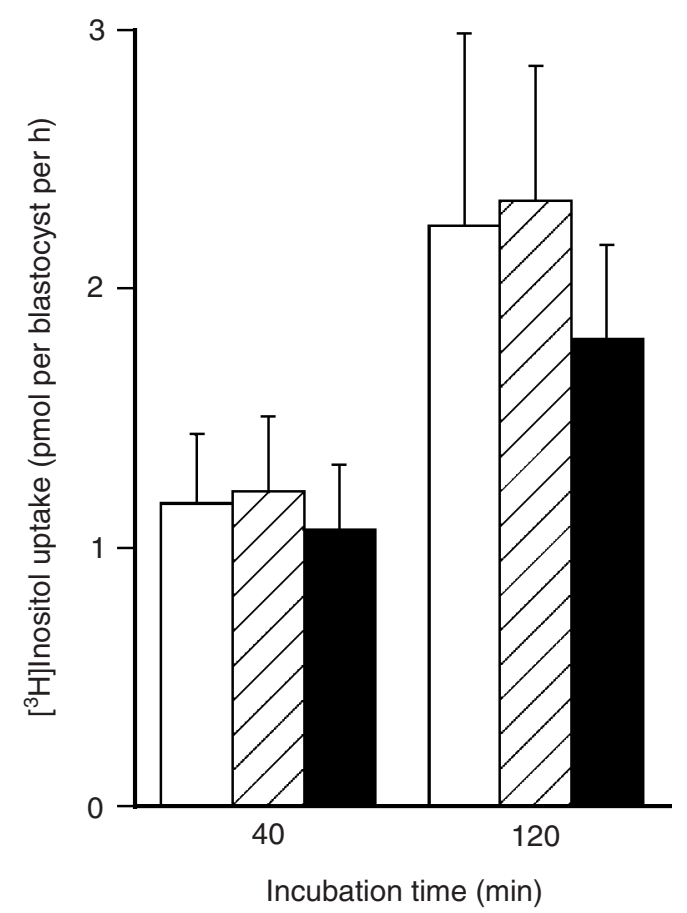

Fig. 8. Effect of osmolality of the incubation medium on uptake of inositol by rabbit morulae and blastocysts. (a) Day 2 early morulae after $40 \mathrm{~min}$ incubation with $50 \mu \mathrm{Ci}\left[{ }^{3} \mathrm{H}\right]$ inositol $\mathrm{ml}^{-1}$ and $3 \mu \mathrm{mol} \mathrm{I}^{-1}$ unlabelled inositol. (b) Day 5 mid-blastocysts with $10 \mu \mathrm{Ci}\left[{ }^{3} \mathrm{H}\right]$ inositol $\mathrm{ml}^{-1}$ and $3 \mu \mathrm{mol}$ unlabelled inositol $\mathrm{I}^{-1}$. Osmolality concentrations (mOsmol (kg water $)^{-1}$ ) were as follows: low $(\square), 180-188$; normal $(\mathbb{E}), 255-262$; high (घ), 340-355. Values are means \pm SEM based on three replicates of 3-8 morulae per treatment (a total of 46 morulae from three rabbits), and 5-6 replicates of one blastocyst per treatment at each time point (33 blastocysts from four rabbits). There was no significant effect of osmolality on inositol uptake by morulae or blastocysts. 
(a)

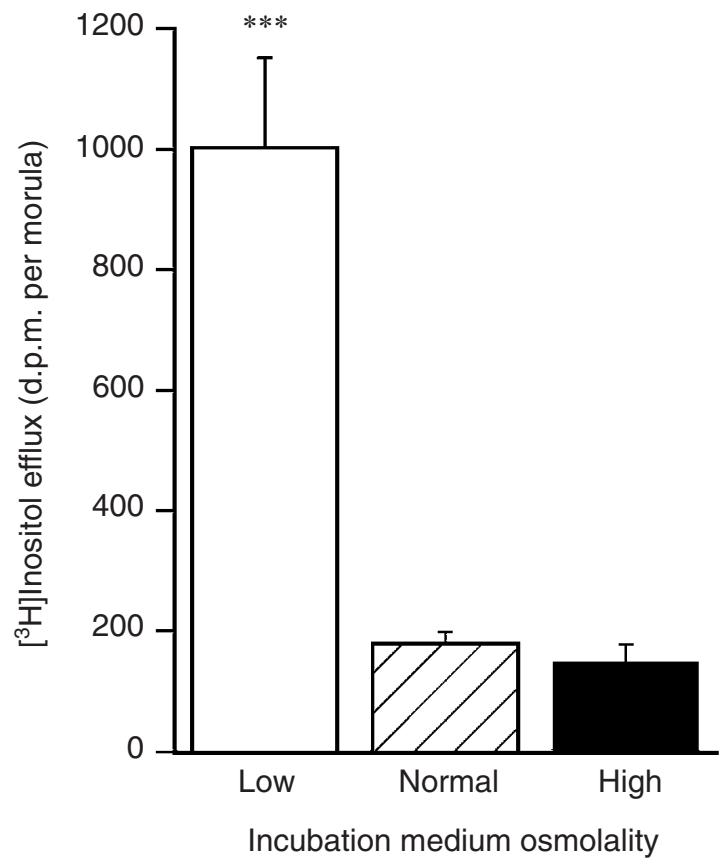

(b)

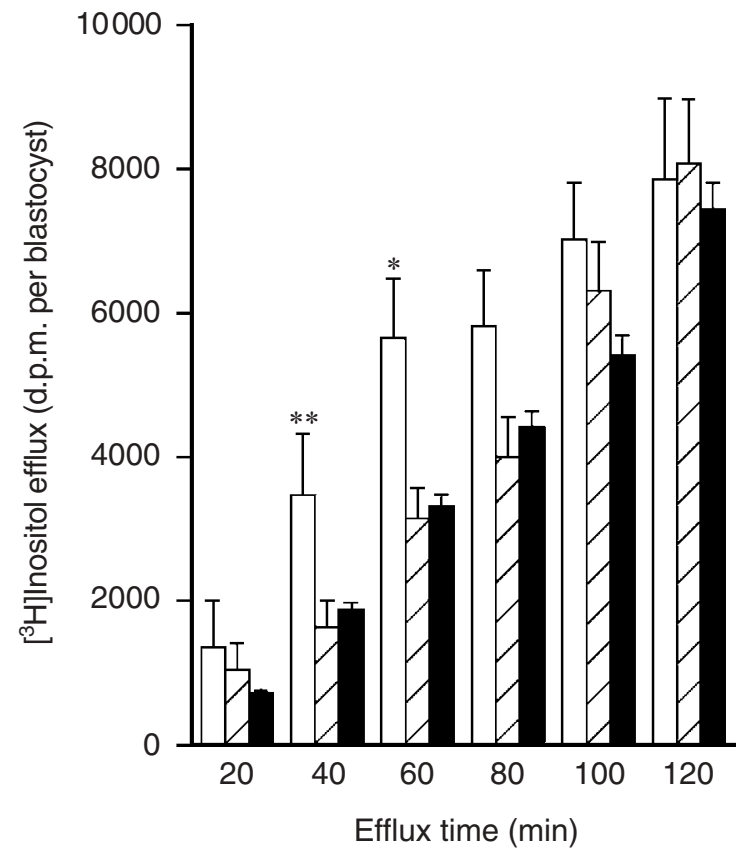

Fig. 9. Effect of osmolality of the incubation medium on efflux of $\left[{ }^{3} \mathrm{H}\right]$ inositol from rabbit morulae and blastocysts. (a) Day 2 early morulae after 40 min of incubation. (b) Day 5 mid-blastocysts. Osmolality concentrations (mOsmol $\left(\mathrm{kg} \mathrm{water}^{-1}\right)$ were as follows: low $(\square)$, 180-188; normal $(\mathbb{E})$, 255-262; high (ם), 340-355. Values at each time point are means \pm SEM based on 23-24 replicates of one blastocyst per treatment (a total of 69 blastocysts from six rabbits). ${ }^{*} P<0.05,{ }^{* *} P<0.01,{ }^{* * *} P<$ 0.001 .

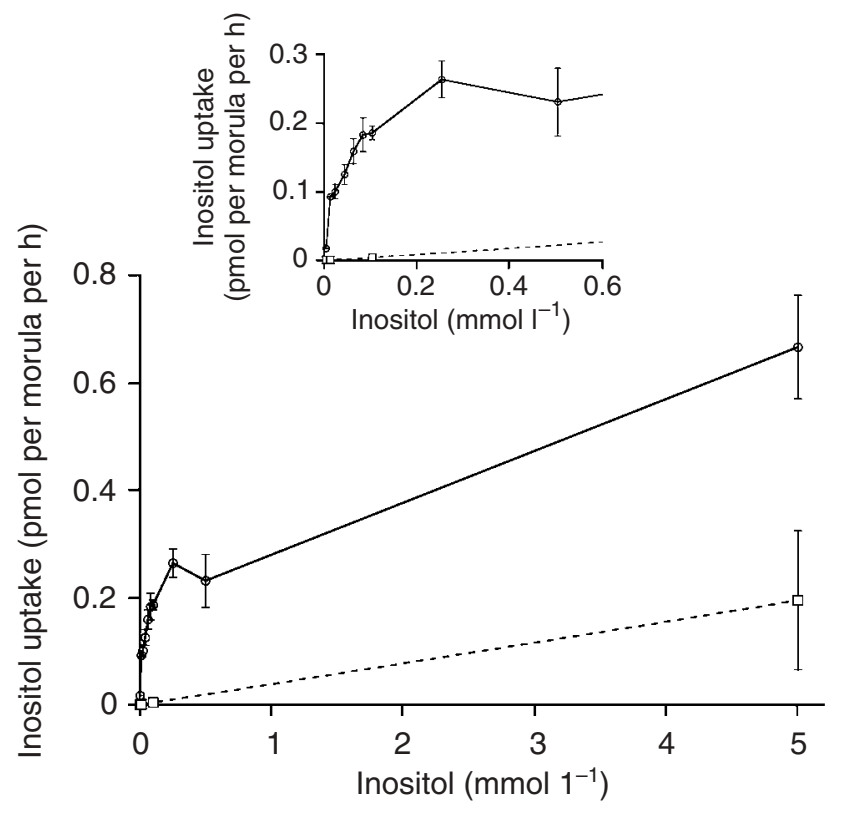

Fig. 10. Effects of inositol concentration in the incubation medium on uptake of inositol by day 2 rabbit early morulae. Plotted points are based on total inositol concentration which includes both labelled and unlabelled inositol. Sodium plus medium, $\bigcirc$; sodium minus medium, $\square$. Inset: uptake in the concentration range 0 $0.6 \mathrm{mmol}_{\text {inositol }} \mathrm{I}^{-1}$. Values are means \pm SEM based on the combined data from two replicate experiments. Details of embryos are provided in Fig. 11. media) from the two replicate experiments are presented (Fig. 11). The values of $V_{\max }$ obtained were 0.224 and 0.288 pmol per embryo per $\mathrm{h}$ and the values of $K_{\mathrm{m}}$ were 45 and $38 \mu \mathrm{mol} \mathrm{I}^{-1}$, respectively.

In contrast, uptake of inositol by whole blastocysts was not saturable from 0 to $5 \mathrm{mmol} \mathrm{I}^{-1}$ (Fig. 12). Data from other experiments (not shown) indicate that even at a concentration of $50 \mathrm{~mol} \mathrm{I}^{-1}$ there was no evidence for saturation of the transport process in blastocysts.

\section{Experiment 8: effect of inositol concentration in the incubation medium on distribution of inositol uptake between blastocyst cells and blastocyst fluid}

Incubation of blastocysts in various concentrations of unlabelled inositol for $2 \mathrm{~h}$ followed by separation of the cells and blastocyst fluid showed that at a low unlabelled inositol concentration in the medium $\left(10 \mu \mathrm{mol} \mathrm{I}^{-1}\right)$, the total amount of inositol taken up into the cells was slightly greater than that in the fluid (Fig. 13); however, with increasing unlabelled inositol concentration, uptake into the cells tended to level off but uptake into the fluid increased in a linear fashion. This finding indicates that either the rate of uptake of inositol into the blastocyst cells or retention by these cells is saturable. The next experiment examined which of these alternatives is valid. 

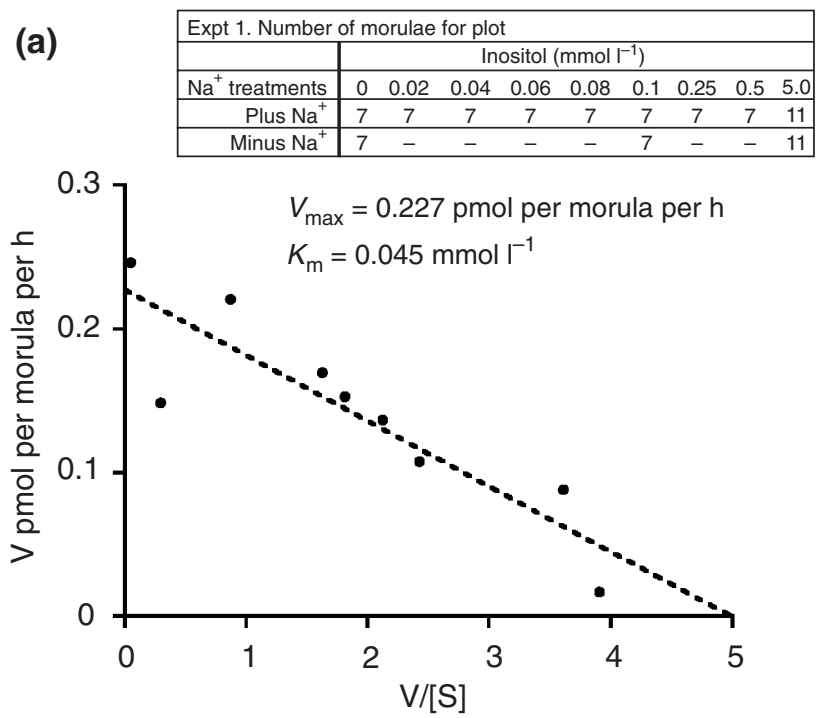
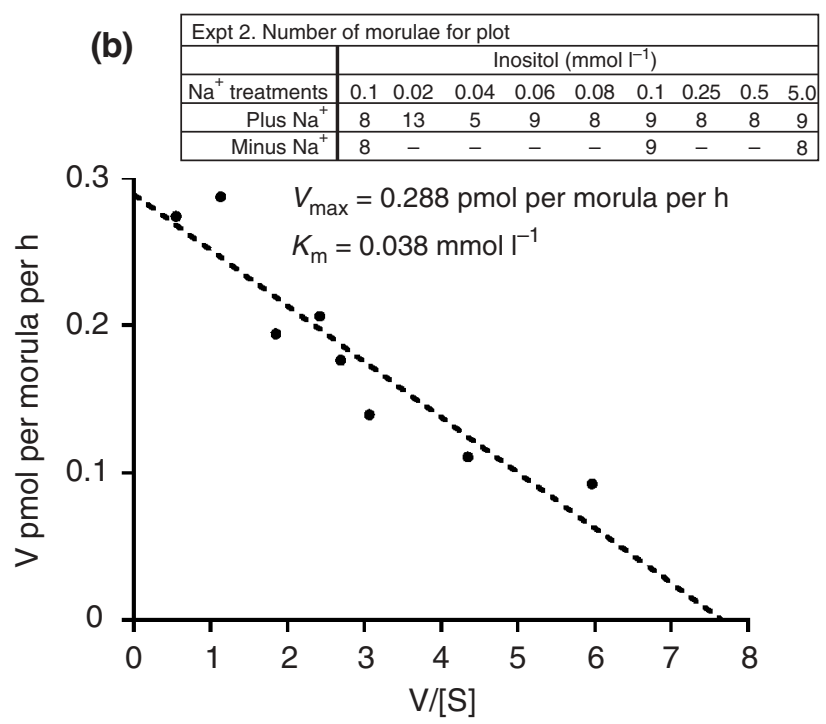

Fig. 11. Kinetics of sodium-dependent inositol transport in rabbit morulae. (a) and (b) are two replicate experiments. Eadie-Hofstee plots for measurement of $K_{\mathrm{m}}$ and $V_{\max }$ values for sodium-dependent transport in day 2 early morulae. $V=$ inositol uptake; $S=$ inositol concentration. Numbers of morulae for each data point are shown in insets.

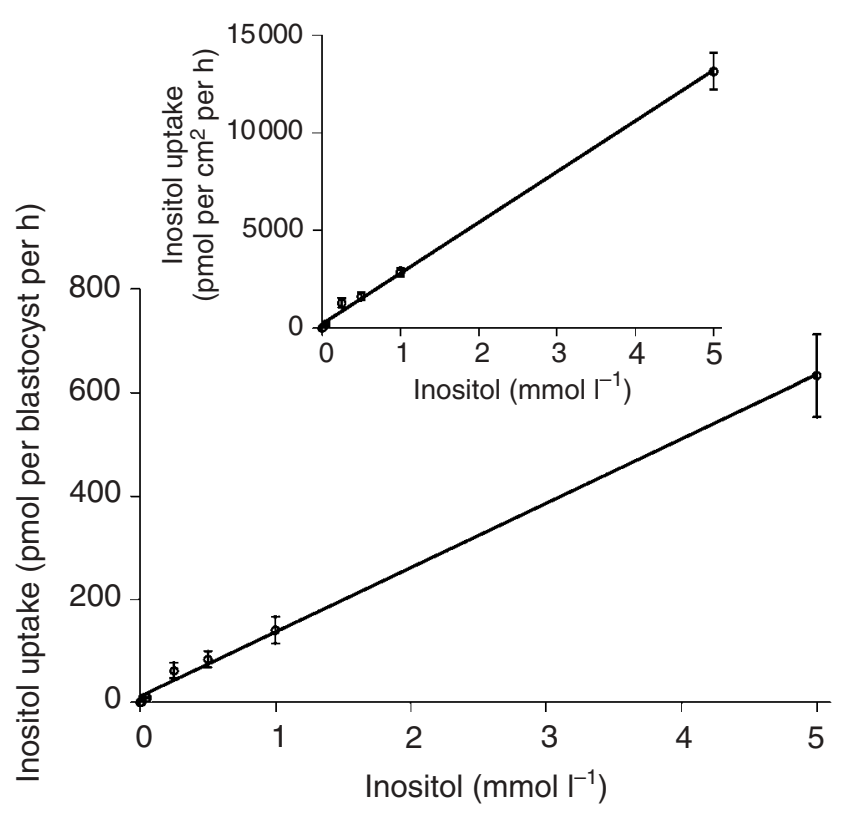

Fig. 12. Effects of inositol concentration in sodium plus incubation medium on uptake of inositol by day 5 rabbit mid-blastocysts. Inset shows uptake per $\mathrm{cm}^{2}$. Results are means \pm SEM based on 7-11 replicates of one blastocyst for each inositol concentration (a total of 60 blastocysts from six rabbits).

\section{Experiment 9: effect of duration of incubation and} concentration of unlabelled inositol on the uptake of $\left.{ }^{3} \mathrm{H}\right]$ inositol by isolated blastocyst cells

When clumped cells from ruptured late blastocysts were incubated for $120 \mathrm{~min}$, a high concentration of unlabelled inositol $\left(5 \mathrm{mmol} \mathrm{I}^{-1}\right)$ markedly reduced

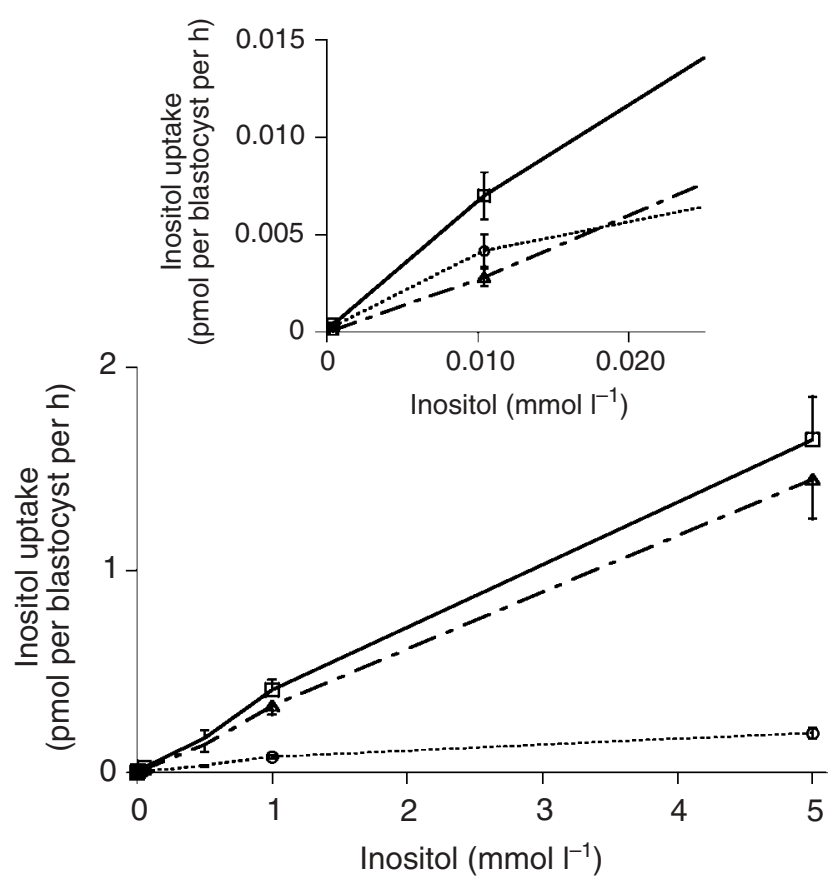

Fig. 13. Effect of inositol concentration in the incubation medium on inositol uptake into different blastocyst (day 6, late blastocysts) compartments (cells and fluid) in rabbits. Total uptake per blastocyst $(\square)$ and uptake into blastocyst cells $(\bigcirc)$ and blastocyst fluid $(\triangle)$ is shown. Values are means \pm SEM based on 6-10 blastocysts per inositol concentration for a total of 57 blastocysts from eight rabbits.

net uptake of $\left[{ }^{3} \mathrm{H}\right]$ inositol compared with a lower concentration $\left(10 \mu \mathrm{mol} \mathrm{I}^{-1}\right.$; Fig. 14). However, when incubation time was reduced to $4 \mathrm{~min}$, the inhibitory effect of the high concentration of unlabelled inositol 
Table 1. Partitioning of $\left[{ }^{3} \mathrm{H}\right]$ inositol uptake between rabbit blastocyst cells and fluid after short-term (2 min) incubation

\begin{tabular}{|c|c|c|c|c|c|c|}
\hline \multirow[t]{2}{*}{$\begin{array}{l}\text { Intact blastocyst } \\
\text { volume }(\mathrm{ml})\end{array}$} & \multicolumn{2}{|c|}{ Blastocyst cell volume $(\mu \mathrm{l})$} & \multicolumn{2}{|c|}{ Blastocyst fluid volume $(\mu \mathrm{l})$} & \multicolumn{2}{|c|}{$\begin{array}{l}\text { Ratio of concentration of }\left[{ }^{3} \mathrm{H}\right] \text { inositol } \\
\text { in blastocyst cells to concentration } \\
\text { in blastocyst fluid }\end{array}$} \\
\hline & Method A & Method B & Method A & Method B & Method A & Method B \\
\hline $12.78 \pm 0.90$ & $0.30 \pm 0.02$ & $0.15 \pm 0.01$ & $12.47 \pm 0.89$ & $12.62 \pm 0.89$ & $9.64 \pm 1.95$ & $17.15 \pm 3.19$ \\
\hline
\end{tabular}

Values are means \pm SEM. Method A: the volume of cells was calculated based on the length of the cell plug in the capillary pipette and the volume of blastocyst fluid was estimated by subtracting that volume from the volume of the blastocyst. Because the plug of cells was not packed by centrifugation this method tends to give an upper limit to the volume of the blastocyst cells. Method B: blastocyst cell volumes were calculated using the equation described by Jung and Fischer (1988) for rabbit blastocysts:

$$
V=\frac{4}{3} \pi\left[r^{3}-(r-s)^{3}\right]
$$

where $V=$ volume of cells, $r=$ blastocyst radius and $s=$ shell or trophoblastic wall thickness (taken as $6 \mu \mathrm{m}$ ).

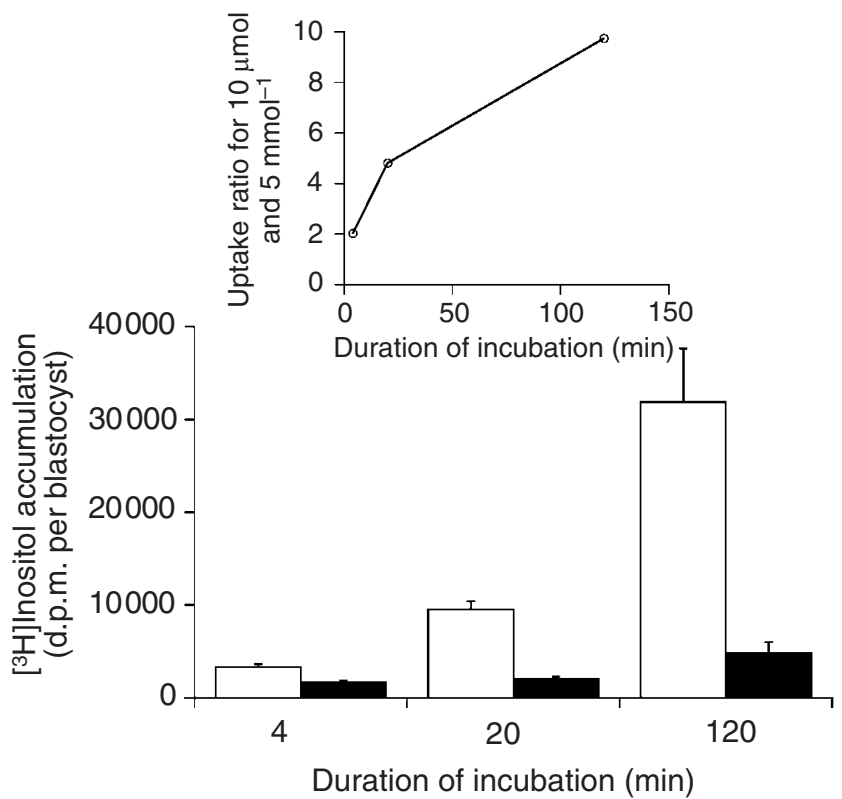

Fig. 14. Effect of duration of incubation and concentration of unlabelled inositol on accumulation of $\left[{ }^{3} \mathrm{H}\right]$ inositol by rabbit blastocyst cells (day 6, late blastocysts). Concentrations of unlabelled inositol: $10 \mu \mathrm{moll}^{-1}(\square) ; 5 \mathrm{mmoll}^{-1}(\mathbf{\square})$. Values are means \pm SEM based on $6-11$ blastocysts per inositol concentration at each time point, for a total of 48 embryos from three rabbits. Inset shows effect of duration of incubation on ratio of accumulated $\left[{ }^{3} \mathrm{H}\right]$ inositol in blastocysts incubated with $10 \mu \mathrm{mol} \mathrm{I}{ }^{-1}$ and $5 \mathrm{mmoll}^{-1}$ unlabelled inositol. There was a significant $(P<0.001)$ effect of both duration of incubation and concentration of unlabelled inositol on uptake of $\left[{ }^{3} \mathrm{H}\right]$ inositol; there was also a significant $(P<0.001)$ interaction between the effect of duration of incubation and concentration of unlabelled inositol on uptake.

was much less marked; extrapolation of the line showing the ratio of inositol uptakes for the two concentrations of unlabelled inositol at different incubation times (Fig. 14, inset) gives a ratio of close to one for an incubation time of $1 \mathrm{~min}$, indicating that high concentrations of unlabelled inositol do not inhibit the initial uptake rate. This result indicates that the uptake process per se in blastocyst cells is not saturable but that there is a saturable binding process for inositol within the cells which affects cellular accumulation and retention of inositol.

\section{Experiment 10: evidence for a cellular versus paracellular entry of inositol into the blastocyst cavity}

Partitioning of $\left[{ }^{3} \mathrm{H}\right]$ inositol taken up by late blastocysts between blastocyst cells and fluid after short-term incubation $(2 \mathrm{~min}$ ) was measured in terms of d.p.m. per unit volume between blastocyst cells and fluid per blastocyst. The mean of the ratios between cells and fluid using the direct measurement method of estimating blastocyst cell volume (method A, Table 1 ) was $9.64 \pm 1.95$ and, using the method of Jung and Fischer (1988), was $17.15 \pm 3.19$ (method B, Table 1$)$. As the concentration is in the region of 9-17-fold higher per unit volume in the blastocyst cells compared with blastocyst fluid after short-term incubation, this indicates that the inositol first enters the blastocyst cells and from there passes into the blastocyst fluid (transcellular route) rather than the other way around. The difference between the two estimates is explainable on the basis that the direct measurement method of obtaining blastocyst cell volume tends to over-estimate the cell volume (Table 1).

\section{Discussion}

Uptake of inositol by rabbit embryos was shown to increase slightly throughout the first 3 days of development and then increase markedly at the blastocyst stage; this increase was due almost entirely to the increase in embryo surface area at the blastocyst stage, as uptake of inositol by blastocysts was highly correlated with blastocyst diameter $(r=0.903)$ and surface area $(r=$ 0.851). This finding is not surprising as the blastocyst largely consists of a sphere with a large cavity surrounded by a layer of trophoblastic or trophectodermal cells. 
As blastocyst protein content is highly correlated $(r=$ 0.934) with surface area (Morgan and Kane, 1993), it is probable that inositol uptake is also highly correlated with blastocyst protein content.

At physiological concentrations of inositol in the incubation medium, the inositol uptake process in cleavage-stage rabbit embryos was mainly sodium dependent, saturable and inhibited by phloridzin, an inhibitor of sodium-dependent hexose transport, whereas the uptake process in blastocyst stages was non-sodium dependent and non-saturable. This situation is different from that in mice and cattle, the only other species examined to date, in which the uptake process is mainly sodium dependent in blastocyst stages (Kane et al., 1992; Hynes et al., 2000); uptake in cleavage-stage cattle embryos is also sodium dependent (Hynes et al., 2000) but the uptake mechanism in cleavage-stage mouse embryos depends on the stage of embryo (Higgins and Kane, 2003).

It is interesting to examine the change in inositol uptake per unit surface area from one-cell to blastocyst. It is possible to use the data for inositol uptake per embryo stage, assume a diameter of approximately $120 \mu \mathrm{m}$ for the cellular portion of the one-cell and early morulae stages (Alliston and Pardee, 1973), take the measured values for the diameters of the early, mid- and late blastocysts, and from these data calculate the embryo surface area and the inositol uptake per $\mathrm{cm}^{2}$ (this cannot be carried out for the late morulae because the sizes of late morulae were not measured and sizes vary due to the start of embryonic growth at this time). The resulting uptake figures in pmol per $\mathrm{cm}^{2}$ are: one-cell embryo, $157 \pm 18.8$; early morulae, $243 \pm 43.8$; early blastocysts, $150 \pm 9.0$; mid-blastocysts, $115 \pm 10.2$; and late blastocysts, $107 \pm 6.6$. These results show that in spite of the marked change in mechanism of uptake from cleavage to blastocyst stages, the rabbit embryo maintains a relatively constant uptake of inositol per unit surface area at all stages of preimplantation development over a range of surface areas from $0.045 \mathrm{~mm}^{2}$ in the onecell embryo to $22.6 \mathrm{~mm}^{2}$ in late blastocysts.

There is evidence from a wide range of tissues that the most common method of inositol uptake by cells is via a sodium-dependent, phloridzin-inhibitable, saturable cotransporter mechanism (for example, hamster intestine, Caspary and Crane, 1970; rat kidney, Whiteside et al., 1991). The responsible gene, the sodium myo-inositol transporter (SMIT) gene, which, in humans, is also called the SLC5A3 gene, has been cloned from cells from dogs (Kwon et al., 1992), cows (Zhou and Cammarata, 1997) and humans (Berry et al., 1995). The evidence in this paper indicates that expression of this gene may be responsible for inositol uptake in cleavage stages of rabbit embryos.

The $K_{\mathrm{m}}$ values for inositol uptake by early morulae (45 and $38 \mu \mathrm{mol} \mathrm{I}{ }^{-1}$ ) in the present study were within the physiological range of inositol concentrations (approxi- mately $120 \mu \mathrm{mol} \mathrm{I}^{-1}$ ) found in the oviductal fluid of the pregnant rabbit (Gregoire et al., 1962). Many sodiumdependent inositol transport systems have $K_{\mathrm{m}}$ values within the range 12-41 $\mu \mathrm{mol} \mathrm{I}^{-1}$ (for review, see GarciaPerez and Burg, 1991) but higher values have been reported, for example, $178 \mathrm{mmol} \mathrm{I}^{-1}$ in cultured renal epithelial cells (Russo et al., 1995). Assuming the protein content of the early rabbit morula is $0.29 \mu \mathrm{g}$ (Morgan and Kane, 1993), the two $V_{\max }$ values from the results of the duplicate experiments presented in this study correspond

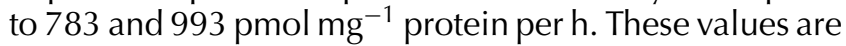
within the range of $V_{\max }$ values found for other systems, for example, $56.8 \mathrm{pmol} \mathrm{mg}^{-1}$ protein per $\mathrm{h}$ for rat renal glomeruli (Whiteside et al., 1991) and $6060 \mathrm{pmol} \mathrm{mg}^{-1}$ protein per $\mathrm{h}$ for cultured rat fetal fibroblasts (Fruen and Lester, 1991). The report of $K_{\mathrm{m}}$ and $V_{\max }$ values for inositol transport in rabbit embryos in the present study is the first report of such values for inositol transport by the preimplantation embryos of any mammalian species.

In addition to the sodium-dependent mechanism of inositol uptake in cleavage-stage embryos in the present study, it is clear that there was also a sodium-independent mechanism of uptake which only became significant at high supra-physiological concentrations of inositol in the incubation medium. This 'lipotropic' (Holub, 1982; Wells, 1989) mechanism may be due to a very low solubility of inositol in the phospholipid layers of the membrane, which allows a limited diffusion across the plasma membrane. The magnitude of the sodium-independent uptake in cleavage stage embryos at physiological concentrations of inositol was probably over-estimated due to the presence of the sodium salts of pyruvate $\left(0.5 \mathrm{mmol} \mathrm{I}^{-1}\right)$ and some amino acids in the sodium minus incubation medium.

Efflux of inositol from early morulae was minimal: about $1.25 \%$ of embryonic content per h compared with $15.6 \%$ for blastocyst stages. The mechanism of this low efflux in morulae may at least partly involve limited diffusion through the membrane. This limited efflux in early morulae indicates that under the conditions of the present experiments the sodium-dependent co-transport mechanism present in cleavage stages is functioning almost entirely in an inward direction.

The mechanism of the sodium-independent uptake in blastocyst stages remains unclear. It is unlikely to be the same mechanism as that responsible for sodiumindependent transport in cleavage stages because of the great increase in sodium-independent transport necessary to maintain the relatively constant rate of uptake per unit surface area observed from cleavage to blastocyst stages. There is evidence in other tissues that sodium-independent inositol transport can take place via chloride channels (Reeves and Cammarata, 1996). In the present study, the effect of temperature on uptake of inositol by blastocyst cells and the fact that the process was not saturable up to a concentration of $50 \mathrm{mmol} \mathrm{I}^{-1}$ in the incubation medium is consistent with a channel 
mechanism. One-cell mouse embryos have been shown to possess chloride channels (Kolajova and Baltz, 1999). The high rate of inositol efflux in blastocysts may take place via the same mechanism as influx. This contention is consistent with the fact that rates of inositol influx and efflux in blastocysts are broadly similar.

There is extensive evidence that inositol can function as an osmolyte which protects cells against osmotic stress; inositol can participate in either regulatory volume increase or decrease (RVI or RVD) in response to osmotic shock (for reviews, see Garcia-Perez and Burg, 1991; Lang et al., 1998). Mouse preimplantation embryo development has been shown to be inhibited by raised osmolality (Dawson and Baltz, 1997), and increased content of $\mathrm{NaCl}$ in the culture medium inhibits rabbit embryo development (Naglee et al., 1969). The expected response to hypertonicity of the incubation medium is an increased rate of inositol uptake as part of an RVI process (Burg, 1995). In the present study, incubation in media of varying osmolality for 40 or $120 \mathrm{~min}$ had no effect on inositol uptake by morulae. The results do not totally exclude such an effect of osmolality on cleavagestage rabbit embryos as the incubation period may have been too short; the effect of hypertonicity on SMIT gene expression and inositol uptake in Madin-Darby canine kidney cells peaks at about 16 and $24 \mathrm{~h}$, respectively (Yamauchi et al., 1993).

The expected response to hypotonicity of the incubation medium is an increased rate of inositol efflux as the cells reduce intracellular osmolality by effluxing osmolytes (RVD). Data from the present study showing a fivefold increase in inositol efflux in the low osmolality medium compared with the control medium provide clear evidence that this mechanism operates in rabbit morulae. There was a similar but much less marked effect of medium hypotonicity in blastocysts in the first 60-80 min after transfer to the hypotonic medium. One reason for the effect being less marked in blastocysts than in morulae may be that efflux may take place both into the blastocoel and the incubation medium. Although the mechanism of this hypotonicity-induced increase in inositol efflux is unknown, it may be similar, at least in cleavage-stage rabbit embryos, to the volume-regulated anion and organic osmolyte channels shown to operate in one-cell mouse embryos (Kolajova and Baltz, 1999; Baltz, 2001). There is one caveat to these and other inositol efflux studies: the possibility that the $\left[{ }^{3} \mathrm{H}\right]$ inositol is metabolized to some other compounds which are effluxed from the cell in response to osmolality changes or that the tritium is transferred to another compound which functions as an osmolyte. However, $\left[{ }^{3} \mathrm{H}\right]$ inositol is used extensively in studies of inositol efflux from cells and there appears to be little evidence in the literature of such problems being significant.

Transport across epithelial layers can occur via either a transcellular or a paracellular route (Stein, 1986). Results from the present study with intact blastocysts, which showed a much higher uptake of inositol per unit volume of blastocyst cells compared with blastocyst fluid after short-term $(2 \mathrm{~min})$ incubation with $\left[{ }^{3} \mathrm{H}\right]$ inositol, indicate that uptake of inositol into the blastocyst takes place via a transcellular route, that is, inositol first passes into the outer trophectodermal layer of cells and then into the blastocyst fluid.

The change from a sodium-dependent mechanism of inositol transport to a sodium-independent mechanism at the morula to blastocyst transition is possibly related to the size and shape of the rabbit blastocyst. At implantation, rabbit blastocysts can have diameters of up to $6 \mathrm{~mm}$ (Alliston and Pardee, 1973), with a resulting low surface area to volume ratio and a large blastocoel. This cavity can readily act as a nutrient store. This nutrient store could facilitate the operation of a nonactive transport system using a diffusion mechanism (possibly through channels) to transport some nutrients such as inositol. The diffusion mechanism could allow uptake by and efflux of inositol from the cells; however, much of the efflux could take place into the blastocyst cavity for later re-uptake into the blastocyst cells. Such a non-active process would have advantages over a sodium-dependent active transport system in terms of energy conservation. It is possible that this type of change in transport mechanism at the morula to blastocyst transition in rabbits may apply to compounds other than inositol.

The results from the present study provide a basis for the study of the phosphatidylinositol system in preimplantation rabbit embryos and illustrate the potential of the rabbit blastocyst as a model system for epithelial transport.

This research was funded by the Health Research Board of Ireland.

\section{References}

Alliston CW and Pardee NR (1973) Variability of embryonic development in the rabbit at 19 to 168 hours after mating Laboratory Animal Science 23 665-670

Baltz JA (2001) Osmoregulation and cell volume regulation in the preimplantation embryo. In Current Topics in Development Vol 52 pp 55-106 Ed. GP Schatten. Academic Press, San Diego

Berridge MJ (1992) Phosphoinositides and cell signaling Fidia Research Foundation Neuroscience Award Lectures 6 5-45

Berry GT, Mallee JJ, Kwon HM, Rim JS, Mulla WR, Muenke M and Spinner NB (1995) The human osmoregulatory $\mathrm{Na}^{+} /$myo-inositol cotransporter gene (SLC5A3): molecular cloning and localization to chromosome 21 Genomics 25 507-513

Burg MB (1995) Molecular basis of osmotic regulation American Journal of Physiology - Renal Fluid and Electrolyte Physiology 37 F983-F996

Caspary WF and Crane RK (1970) Active transport of myo-inositol and its relation to the sugar transport system in hamster small intestine Biochimica et Biophysica Acta 203 308-316

Daniel JC, Jr (1964) Early growth of rabbit trophoblast American Naturalist 98 85-97

Dawson KM and Baltz JM (1997) Organic osmolytes and embryos: substrates of the Gly and $\beta$ transport systems protect mouse zygotes 
against the effects of raised osmolarity Biology of Reproduction $\mathbf{5 6}$ 15501558

Fahy MM and Kane MT (1992) Inositol stimulates DNA and protein synthesis, and expansion by rabbit blastocysts in vitro. Human Reproduction 7 550-552

Fahy MM and Kane MT (1993) Incorporation of $\left[{ }^{3} \mathrm{H}\right]$ inositol into phosphoinositides and inositol phosphates by rabbit blastocysts Molecular Reproduction and Development 34 391-395

Ferguson MAJ (1999) The structure, biosynthesis and functions of glycosylphosphatidylinositol anchors, and the contributions of trypanosome research Journal of Cell Science 112 2799-2809

Fruen BR and Lester BR (1991) High-affinity $\left[{ }^{3} \mathrm{H}\right]$ inositol uptake by dissociated brain cells and cultured fibroblasts from fetal mice Neurochemical Research 16 913-918

Garcia-Perez A and Burg MB (1991) Renal medullary organic osmolytes Physiological Reviews 71 1081-1115

Green CJ (1975) Neuroleptanalgesic drug combinations in the anaesthetic management of small laboratory animals Laboratory Animals 9 $161-178$

Gregoire AT, Gongsakdi D and Rakoff AE (1962) The presence of inositol in genital tract secretions of the female rabbit Fertility and Sterility $\mathbf{1 3}$ 432-435

Ham RG (1963) An improved nutrient solution for diploid Chinese hamster and human cell lines Experimental Cell Research 29 515-526

Higgins BD and Kane MT (2003) Inositol transport in mouse oocyte and preimplantation embryos: effects of mouse strain, embryo stage, sodium and the hexose transport inhibitor, phloridzin Reproduction $125111-$ 118

Holub BJ (1982) The nutritional significance, metabolism, and function of myo-inositol and phosphatidylinositol in health and disease. In Advances in Nutritional Research Vol 4 pp 107-141 Ed. HH Draper. Plenum, New York

Hynes AC, Sreenan JM and Kane MT (2000) Uptake and incorporation of myo-inositol by bovine preimplantation embryos from two-cell to early blastocyst stages Molecular Reproduction and Development 55 265269

Jones DR and Varela-Nieto I (1998) The role of glycosylphosphatidylinositol in signal transduction International Journal of Biochemistry and Cell Biology 30 313-326

Jung T and Fischer B (1988) Correlation between diameter and DNA or protein synthetic activity in rabbit blastocysts Biology of Reproduction 39 1111-1116

Kane MT (1987) In vitro growth of preimplantation rabbit embryos. In The Mammalian Preimplantation Embryo: Regulation of Growth and Differentiation In Vitro pp 193-217 Ed. BD Bavister. Plenum Press, New York

Kane MT (1988) The effects of water soluble vitamins on the expansion of rabbit blastocysts Journal of Experimental Zoology 245 220-223

Kane MT (1989) Effects of the putative phospholipid precursors, inositol, choline, serine and ethanolamine, on formation and expansion of rabbit blastocysts in vitro. Journal of Reproduction and Fertility 87 275-279

Kane MT and Bavister BD (1988) Vitamin requirements for development of eight-cell hamster embryos to hatching blastocysts in vitro. Biology of Reproduction 39 1137-1143

Kane MT and Foote RH (1970) Culture of two-and four-cell rabbit embryos to the expanding blastocyst stage in synthetic media Proceedings of the Society for Experimental Biology and Medicine 133 921-925

Kane MT, Norris M and Harrison RAP (1992) Uptake and incorporation of inositol by preimplantation mouse embryos Journal of Reproduction and Fertility 96 617-625

Kleinzeller A and Ziyadeh FN (1990) Cell volume regulation in epithelia - with emphasis on the role of osmolytes and the cytoskeleton. In Cell Volume Regulation pp 59-86 Ed. KW Beyenbach. Karger, Basel
Kolajova M and Baltz JM (1999) Volume-regulated anion and organic osmolyte channels in mouse zygotes Biology of Reproduction 60964 972

Kwon HM, Yamauchi A, Uchida S, Preston AS, Garcia-Perez A, Burg MB and Handler JS (1992) Cloning of the cDNA for a $\mathrm{Na}^{+} / m y o-$ inositol cotransporter, a hypertonicity stress protein Journal of Biological Chemistry 267 6297-6301

Lang F, Busch GL and VolkI H (1998) The diversity of volume regulatory mechanisms Cellular Physiology and Biochemistry 8 1-45

Leevers SJ, Vanhaesebroeck B and Waterfield MD (1999) Signalling through phosphoinositide 3-kinases: the lipids take centre stage Current Opinion in Cell Biology 11 219-225

Morgan PM and Kane MT (1993) Protein content of rabbit embryos: one cell to peri-implantation blastocysts Journal of Reproduction and Fertility $\mathbf{9 7}$ 101-106

Naglee DL, Maurer RR and Foote RH (1969) Effect of osmolarity on in vitro development of rabbit embryos in a chemically defined medium Experimental Cell Research 58 331-333

Reeves RE and Cammarata PR (1996) Osmoregulatory alterations in myoinositol uptake by bovine lens epithelial cells. Part 5. Mechanism of the myo-inositol efflux pathway Investigative Ophthalmology and Visual Science 37 619-629

Robinson DH, Smith PR and Benos DJ (1990) Hexose transport in preimplantation rabbit blastocysts Journal of Reproduction and Fertility 89 1-11

Russo LM, Marano CW, Hagee MM, Laughlin KV, Guy A, Varimbi S and Mullin JM (1995) Sodium-independent carrier-mediated inositol transport in cultured renal epithelial (LLC-PK1) cells Biochimica et Biophysica Acta 1236 15-22

Schiffner J and Spielmann H (1976) Fluorometric assay of the protein content of mouse and rat embryos during preimplantation development Journal of Reproduction and Fertility 47 145-147

Schultz SG and Zalusky R (1964) Ion transport in isolated rabbit ileum. II. The interaction between active sodium and active sugar transport Journal of General Physiology 47 1043-1059

Shears SB (1998) The versatility of inositol phosphates as cellular signals Biochimica et Biophysica Acta 1436 49-67

Steel RGD and Torie JH (1960) Principles and Procedures of Statistics. McGraw-Hill Book Company Inc., New York

Stein WD (1986) Transport and Diffusion Across Cell Membranes. Academic Press, Orlando

Varticovski L, Harrison-Findik D, Keeler ML and Susa M (1994) Role of PI 3-kinase in mitogenesis Biochimica et Biophysica Acta 1226 1-11

Wells WW (1989) Inositol deficiency states as a guide to inositol function. In Inositol Lipids in Cell Signalling pp 207-235 Eds RH Michell, AH Drummond and CP Downes. Academic Press, London

Whiteside Cl, Thompson JC and Ohayon J (1991) Myo-inositol and D-glucose transport in rat glomerular and cultured mesangial cells American Journal of Physiology 260 F138-F144

Yamauchi A, Uchida S, Preston AS, Kwon HM and Handler JS (1993) Hypertonicity stimulates transcription of gene for $\mathrm{Na}^{+}$-myo-inositol cotransporter in MDCK cells American Journal of Physiology 264 F20F23

Zhou C and Cammarata PR (1997) Cloning the bovine $\mathrm{Na}^{+} / m y o$-inositol cotransporter gene and characterization of an osmotic responsive promoter Experimental Eye Research 65 349-363

Received 23 August 2002.

First decision 11 October 2002.

Revised manuscript received 25 November 2002.

Accepted 12 December 2002. 